\title{
Suitability Checks and Household Investments in Structured Products ${ }^{*}$
}

\author{
Eric C. Chang \\ Faculty of Business and Economics \\ The University of Hong Kong \\ E-mail: ecchang@,hku.hk \\ Dragon Yongjun Tang \\ Faculty of Business and Economics \\ The University of Hong Kong \\ E-mail: yjtang@,hku.hk \\ Miao (Ben) Zhang \\ McCombs School of Business \\ The University of Texas at Austin \\ E-mail: miao.zhang@utexas.edu
}

July 11,2013

\begin{abstract}
The suitability of complex financial products for household investors is an important issue in light of consumer financial protection. The U.S. Dodd-Frank Act, for instance, mandates that distributors check suitability when selling structured products to retail investors. However, little empirical evidence exists on such transactions. Using data from Hong Kong, we find that investors purchase 8\% more structured products, on average, when the suitability is not checked. The effect of suitability checks is more pronounced for less financially literate investors. Moreover, investors tend to buy products with lower risk-adjusted returns when product suitability is not checked.
\end{abstract}

\footnotetext{
*We thank John Beshears, William Goetzmann, John Griffin, Bing Han, Gerard Hoberg, Alok Kumar, Kelvin Law, Yu-Jane Liu, Neil Pearson, Mark Seasholes, Tao Shu, Avanidhar Subrahmanyam, Wing Suen, Sheridan Titman, Chun Xia, Hong Yan, Chu Zhang, Hao Zhou, Ning Zhu, and especially an anonymous referee and the editor Stephen Brown for helpful discussions and useful comments. We thank seminar participants at Singapore Management University, Peking University, University of Hong Kong, Hong Kong Polytechnic University, the University of Texas at Austin, 2009 SFM Conference at National Sun Yat-Sen University, 2010 HitotsubashiThammasat Conference on Asian Financial Market, 2010 Emerging Market Finance Conference at Tsinghua University, 2010 Financial Management Association Annual Meeting, and 2011 Asian Finance Association Annual Meeting. We thank Ying Deng, Kathy Griffin, and Susan Chenyu Shan for editorial assistance. Support from the Small Project Grant, the Centre for Financial Innovation and Risk Management, and the Asia Case Research Centre of the University of Hong Kong is acknowledged.
} 


\title{
Suitability Checks and Household Investments in Structured Products
}

\begin{abstract}
The suitability of complex financial products for household investors is an important issue in light of consumer financial protection. The U.S. Dodd-Frank Act, for instance, mandates that distributors check suitability when selling structured products to retail investors. However, little empirical evidence exists on such transactions. Using data from Hong Kong, we find that investors purchase $8 \%$ more structured products, on average, when the suitability is not checked. The effect of suitability checks is more pronounced for less financially literate investors. Moreover, investors tend to buy products with lower risk-adjusted returns when product suitability is not checked.
\end{abstract}




\section{Introduction}

Retail structured products are an important yet controversial component of the global financial market. Individual investors in the U.S. have suffered multi-billion-dollar losses in structured product investments (Wasik (2011)). Consequently, financial regulators worldwide are taking stringent measures to protect investors in retail structured product markets. Most notably, in the U.S., the Consumer Financial Protection Bureau, founded in 2011 as a result of the DoddFrank Act, requires distributors to check the suitability of structured products for retail clients. ${ }^{1}$ However, little hard evidence has been produced to justify such regulations, which may not achieve the desired goals and could even have unintended consequences (see, e.g., Benmelech and Moskowitz (2010)). Given that protection is necessary only when investors are unable to "fend for themselves", it is important to study the actual investment experience. Indeed, Campbell, Jackson, Madrian, and Tufano (2011) see "an urgent need" for empirical analyses to reveal the cross-sectional variations in financial decision-making using household-level field data.

Structured products are derivatives with a customized payoff structure synthetically linked to a reference security or a basket of securities. The retail market for structured products has grown rapidly since its inception in the mid-1990s. Global new issuance reached $\$ 400$ billion

\footnotetext{
${ }^{1}$ Many other countries are also taking similar action. The U.K. is in the process of establishing the Consumer Protection and Markets Authority. Norway amended its securities law in February 2008 to effectively ban retail structured products. Singapore barred ten firms from selling structured products in September 2009. In June 2011, the Financial Services Authority (FSA) of the U.K. (http://www.fsa.gov.uk/pubs/cp/cp11_11.pdf) and the Securities and Exchange Commission (SEC) and the Financial Industry Regulatory Authority (FINRA) of the U.S (http://www.finra.org/Newsroom/NewsReleases-/2011/P123744) warned issuers, distributors, and investors about retail structured products.
} 
in 2007 and the total sales in the U.S. alone reached \$54 billion in $2010 .^{2}$ However, the strong demand for structured products from retail investors is perplexing. Henderson and Pearson (2011) document that the SPARQS, a popular set of equity-linked structured products in the U.S., have negative expected returns on average. ${ }^{3}$ They conclude that "it is difficult to rationalize their purchases by informed rational investors". Moreover, these products are new and complex, therefore not in keeping with the conventional evidence that people prefer familiar assets (Cao, Han, Hirshleifer, and Zhang (2011)). Given that structured products have often turned out to be risky investments, it is important to understand household investors' allocation to structured products.

We empirically study household investments in structured products using a unique transactions dataset from Hong Kong, where structured product investment has been a contentious issue in recent years. Despite the city being praised by Milton Friedman (1997) as the best example of a free economy and consistently being ranked first in the Index of Economic Freedom, the Hong Kong government took the unprecedented step of pressuring the distributing banks to buy back many structured products. Our study focuses on this intriguing episode using Hong Kong data. Our findings can also provide useful implications on investor protection in other markets.

\footnotetext{
${ }^{2}$ The numbers are from StructuredRetailProducts.com. The total amount of outstanding structured products in the retail market was around $\$ 1,270$ billion in 2007. A survey in January 2011 commissioned by the Financial Times reports that $40 \%$ of individual investors in the U.K. own structured products (http://www.ft.com/intl/cms/s/2/25729692-3b8b-11e0-a96d-00144feabdc0.html\#axzz1P4xvIDoS. Survey results are available at https://www.dianomi.com/-uploads/dianomi-investorsurvey-H1-2011.pdf).

${ }^{3}$ The overpricing of retail structured products is also documented by Bergstresser (2008) based on more than 1,000,000 structured notes issued globally between 1995 and 2008. Stoimenov and Wilkens (2005) and Li and Zhang (2011) also find structured products overpriced in Germany and Hong Kong.
} 
Our focus is the role of product suitability checks in investment allocations. Given recent findings on the overpricing of structured products by Henderson and Pearson (2011), understanding the determinants of structured product market participation is an interesting and important topic by itself. However, our data does not allow us to investigate investor choice between structured products and other investment opportunities. Nevertheless, we believe that the allocation data provides us a rare opportunity to explore financial decision-making (prior studies often rely on participation data). Our investigation of the suitability check is best linked to allocation data.

Many may sensibly dismiss the potential influence of a suitability check on product purchase as investment decisions are commonly believed to be largely determined by investor background including financial literacy. However, the suitability check is a key element of the newly minted regulations on consumer financial protection concerning important issues such as mis-selling (Inderst and Ottaviani (2009)). The Hong Kong market provides a unique setting for our empirical research design. For unlisted retail structured products transactions over-thecounter (OTC), Hong Kong securities regulations stipulate that salespeople check product suitability before processing the purchase. Specifically, product distributors are required by the Securities and Futures Commission (SFC) to lead an investor through a questionnaire on his or her risk profile and compare this with the product's risk level to determine whether the product is suitable for the investor. Failing to do so could result in severe penalties. If the product's risk level is beyond the investor's risk tolerance, the investor can still buy the product but he must sign an agreement acknowledging that he is taking excessive risk. In practice, the suitability check is pro-forma in nature and often not handled rigorously, and some transactions are completed without product suitability checks. We exploit this aspect of the transaction process and examine whether the suitability checks have any effect on the subsequent investment outcomes, particularly the amount that individuals invest. 
We compile data on retail structured product transactions through individual face-to-face interviews. Comprehensive investor characteristics and transaction procedure information are matched to product data. Structured product market participants and non-participants in our sample are similar in terms of age and income. We focus on the suitability check effect on investment allocation conditioned on participation, as we only observe the status of suitability checks for those who have bought structured products. We find that these investors allocate about $8 \%$ more of their financial wealth to structured products, on average, when the product suitability is not checked before purchase. High income earners allocate less proportion to structured products. The suitability check effect is robust to controls for investor profile, product characteristics, and market conditions. Compared to other explanatory variables examined, the suitability check has the strongest explanatory power for structured product investments.

Product suitability checks were not conducted for about half of our sample transactions even though they were required by regulators. It is the salesperson's responsibility to check for product suitability even if investors do not care about this procedure, so it is possible that salespeople selectively neglect suitability checks for their own interests. The model of Inderst and Ottaviani (2009) suggests some transactions may be completed without suitability checks because suitability standards depend on distributors' compliance costs and sales force incentives. We find that suitability checks are skipped more often when the market interest rate is high, which is also when the competition for selling is likely high because it is harder to beat other investment opportunities.

One concern is that the suitability check is likely to be endogenous. We use an instrumental variable (IV) approach to address the endogeneity concern in suitability checks. Our IV is investor's leverage status or whether the investor is in debt even though he is investing in structured products. We show that suitability is less likely to be checked for leveraged investors. Moreover, investor leverage status is not a weak IV. Conventional theories suggest that the 
source of capital should not affect investment allocation. Therefore, it seems valid to exclude the investor leverage position from the investment allocation analysis. However, investor leverage status can affect investment allocation via the suitability check. Indeed, using this instrumental variable in a two-stage analysis, we find that the instrumented suitability check is also significantly related to structured product allocation. We further address the endogeneity concern using the propensity score matching approach and find that structured product allocation is higher when suitability is not checked even for transactions with a high propensity towards suitability checks.

Why is investment allocation to structured products higher when suitability is not checked? We suggest that two mechanisms seem to offer the only plausible explanations. The first mechanism is learning. If investors learn about product risk during the suitability check, then they may buy less after the suitability check. This mechanism is derived from the "neglected risks" model of Gennaioli, Shleifer, and Vishny (2012) which predicts that excess purchase of structured products is related to buyers' neglect of bad states. The second mechanism is driven by a selling incentive: salespeople deliberately skip the suitability check in order to complete the transaction as fast as possible in order to earn more commission. We use investor's knowledge about the products and financial literacy to examine these two mechanisms. Learning from suitability checks and a strategic choice by salespeople should have less influence on investors who are more financially literate. Our findings are consistent with this conjecture and provide support for both mechanisms. The effect of the suitability check on structured product investment is more pronounced for less financially literate investors.

We further find that a suitability check affects the welfare of structured product investors. Without product suitability checks, not only do investors buy more structured products, they also buy products that have lower risk-adjusted returns. However, those products are likely more profitable for the distributors. Therefore, our evidence seems consistent with the theoretical 
framework of Inderst and Ottaviani (2009) that distributors put their interests before their customers. This result on product value is also consistent with the "reverse causality" mechanism that a suitability check is intentionally neglected by salespeople to facilitate profitable transactions (SEC (2011)).

Our study contributes to the literature in the following ways. First, the results help us understand the "dark side of financial innovation" demonstrated by Henderson and Pearson (2011) using data on structured equity products traded on exchanges. Our study complements their work by focusing on structured credit products purchased over-the-counter and emphasizing the issue of product suitability. Second, we contribute to the growing literature on household finance (Campbell (2006)) and consumer finance (Tufano (2009)). This paper is the first empirical study, to our knowledge, on household portfolio allocation to structured products using field data. We show that a suitability check has a distinct effect, and its effect is most pronounced among people with lower financial literacy. Moreover, our findings add context to theoretical models on the protection of uninformed investors who rely on the advice of financial intermediaries (Carlin and Gervais (2012), Inderst and Ottaviani (2012)).

The remainder of the paper is organized as follows: Section 2 describes the structured products market and transaction data in Hong Kong. Our main empirical findings on the relationship between suitability checks and structured product investments are presented in Section 3. We conclude in Section 4.

\section{Household Investments in Structured Products: Data from Hong Kong}

\subsection{The Retail Structured Product Market in Hong Kong}


Hong Kong has an active market for derivatives and structured products (the derivative warrants turnover became number one in the world in $2003^{4}$ ). The size of its retail structured products market has increased rapidly, from US\$0.6 billion in 2002 to US\$44.3 billion in $2007 .^{5}$

The issuance of retail structured notes in Hong Kong was regulated less strictly before 2011. ${ }^{6}$ The only oversight was an authorization required from the Securities and Futures Commission (SFC) for distributing prospectuses and marketing materials. However, product suitability for investors is the SFC's major concern. The issuing prospectuses of our sample structured notes include the following statement: "Under the SFC Code of Conduct, Distributors in Hong Kong, as entities licensed by or registered with the SFC, are required to ensure that the suitability of the Notes to a prospective investor is reasonable in all circumstances and to ensure that the prospective investor understands the nature and risks of investing in the Notes." To check product suitability, salespeople work with the client in person to fill out a questionnaire about investor information and product features.

The suitability check is pro-forma in nature and makes up only part of the many forms that investors need to sign. Bank staff collect investor background information for the "Know Your Client (KYC)" form and the banks use risk profiling tests to categorize their clients into different risk tolerance levels from low to high. Before distributing structured products, the banks also assign them risk ratings from low to high. A product is suitable for a customer if its risk rating is below or equal to the investor's risk tolerance level. If the product risk is higher than his tolerance, the investor needs to sign an agreement to acknowledge that he is taking excessive risk (banks will not be responsible for such conscious unsuitable investments).

\footnotetext{
${ }^{4}$ http://www.hkex.com.hk/eng/newsconsul/newsltr/2005/documents/2005-01-12-e.pdf

${ }^{5}$ Data is provided by www.structuredretailproducts.com.

${ }^{6}$ Since June 2011, structured products publicly offered to nonprofessional investors are regulated by the Securities and Futures Commission (SFC) of Hong Kong. The SFC now also requires a post-sales cooling off period for unlisted retail structured products.
} 
Although the distributing banks have internal control policies mandating product suitability checks, this procedure is not always adhered to. Many structured products have been sold to customers without suitability checks prior to purchase, or to customers whose risk tolerance levels were below product risk ratings but without customers' acknowledgement. Salespeople have sometimes provided a make-up suitability check after the transaction. Other more outrageous offenses include forged forms and asking clients to sign a blank paper on which the forms would be printed in future. These transactions lack proper suitability checks and may have been driven by poorly trained or commission focused selling agents. ${ }^{7}$ The SFC has investigated and uncovered issues regarding the lack of suitability checks. ${ }^{8}$

Unlisted retail structured products provide a good setting to study investment decisions and the potential effect of a suitability check. Rich information can be recorded during over-thecounter transactions (by contrast, only price and quantity data are available for exchange listed securities transactions). Unlisted products also usually do not have a secondary market and are very difficult to liquidate before their maturity date. Therefore, investors are expected to be cautious with such investments. Ultimately, whether a suitability check will have any effect or not is best answered with field data.

\subsection{Credit-linked Notes (CLN) Structure: An Example}

An important constituent of the unlisted structured product market, and also a majority of our sample, is credit-linked notes (CLNs). According to SFC reports by Lee and Chang (2005,

\footnotetext{
${ }^{7}$ Investor oversight does not apply to non-professional investors. Even if investors do not want to have a suitability check, salespeople still have a responsibility to follow the proper procedures, as clearly stated in the SFC quote.

${ }^{8}$ See, e.g, http://www.sfc.hk/sfcPressRelease/EN/sfcOpenDocServlet?docno=11PR71 and http://www.sfc.hk/edistributionWeb/gateway/EN/news-and-announcements/news/enforcement-news/doc?refNo=12PR130. The distributing banks are also regulated by the Hong Kong Monetary Authority (HKMA, the central bank of Hong Kong). The HKMA has taken disciplinary actions against bank staff for failing to disclose product risk, see http://www.info.gov.hk/hkma/eng/press/2009/20091120e3.htm, http://www.info.gov.hk/hkma/eng/press/2010/20100514e5.htm
} 
2006), CLNs account for about $35 \%$ of the unlisted retail structured product market. Lehman Brothers Asia arranged the Minibond series which accounted for about 47\% of the CLN market. DBS Constellation series accounted for about $32 \%$ of the CLN market.

We illustrate in Figure 1 the structure of Minibond Series 35 as an example. (Other Minibond series have a very similar structure to Minibond 35.) This CLN was arranged by Lehman Brothers Asia for the issuer Pacific International Finance Limited, an SPV incorporated in the Cayman Islands, on February 22, 2008 (the offering started on January 16, 2008), and distributed through nine commercial banks and two securities firms. The maturity is 3 years but the notes are callable at $100 \%$ principal value after one year. Annual coupon rates (paid quarterly) are $6.0 \%$ for tranche $\mathrm{A}$ with a US\$5,000 denomination and 5.6\% for tranche $\mathrm{B}$ with a HK $\$ 40,000$ denomination (the HKD is pegged to the USD at about US\$1.0 $=$ HK $\$ 7.8$ ).

The payoffs of Minibond 35 are linked to the credit events of 7 reference entities (their Moody's/S\&P credit ratings in brackets): HSBC Bank PLC (Aa2/AA-), Hutchison Whampoa Limited (A3/A-), MTR Corporation Limited (Aa2/AA), the People's Republic of China (A1/A), Standard Chartered Bank (A3/A), Sun Hung Kai Properties Limited (A1/A) and Swire Pacific Limited (A3/A-). Credit events including bankruptcy are defined in the prospectus. When the first credit event from those seven reference entities occurs, the notes will be redeemed and the maximum redemption value will be determined largely by the recovery rate of the reference issues associated with the credit event. Investors are essentially selling insurance against the default of any the reference entities. In other words, they are sellers of credit default swaps (CDS) for this basket of seven reference entities. The buyer of the CDS for Minibond 35 is the swap counterparty Lehman Brothers Special Financing. The structured notes are secured by collaterals which are purchased with the issue proceeds. (The collateral asset for Minibond 35 is a collateralized debt obligation (CDO) called Beryl 2008-2.) Therefore, besides the expected loss 
associated with the first-to-default of reference entities, collateral risk and swap counterparty risk also affect the redemption value of the notes.

Minibonds were the first CLNs in Hong Kong. Other notes subsequently entered the market, most noticeably Constellation notes, which are similar to Minibonds in structure. One major difference is that Minibonds are typically linked to Hong Kong local Chinese names while Constellation notes are often linked to established international financial firms. For example, Constellation notes 35-37, offered in February 2006, are linked to JPMorgan Chase, Merrill Lynch, Morgan Stanley, Goldman Sachs, Lehman Brothers, Prudential, AXA, and Bank of East Asia. In particular, many Constellation notes are linked to Lehman Brothers. Constellation notes and Minibonds are usually offered in alternate months. Also, there is some heterogeneity in yield and maturity between these two CLN series.

\subsection{Data Compilation and Descriptive Statistics}

Compiling household structured product investment data is not always feasible as distributors do not share investors' information with third parties. We took advantage of an opportunity created by the bankruptcy of Lehman Brothers in September 2008, upon which individual investors in Hong Kong learned that their investment products were much riskier than they thought. For products linked to Lehman Brothers, the risk came from the credit event of reference entities. For other products arranged by Lehman Brothers, the risk came from the drop in collateral value and the loss from the swap contracts resulting from counterparty default. Structured product investors in Hong Kong formed discussion groups to share thoughts and information. We collected investor transaction data via individual face-to-face interviews. Our interviews were conducted at different times (daytime and evening), different dates (weekdays and weekends), and different locations (offices and open areas in both Hong Kong Island and Kowloon). Each interview took about 15-30 minutes. In total, eleven rounds of interviews were conducted from January to June 2009. 
Many of our sample investors bought Lehman Brothers related CLNs (Minibonds arranged by Lehman Brothers and Constellation notes linked to Lehman Brothers) between 2003 and 2008. We have detailed product information for such investments and we use them as our base sample. We also interviewed investors who invested in structured products where the product information was incomplete (some of them bought equity-linked notes). This smaller sample is used for auxiliary analysis. Furthermore, we collected data from investors who did not buy structured products. This group of investors is used for our market participation analysis.

Table 1 provides summary statistics of our base sample of 221 investors. We aggregate all structured product investment at investor level in case of multiple purchases. Investors put $60.3 \%$ of their financial wealth in structured products, on average. The average investor age is 55 . In terms of education, $48.4 \%$ of them have not completed high school. It is conceivable that many investors in our sample who are relatively old and little educated may have viewed structured products as low-risk bonds, hence, allocated a substantial amount of their wealth to those notes. ${ }^{9}$

To check the general reliability of our sample, we compare our sample including all observations to the Hong Kong By-Census 2006 covering 5.1 million citizens. ${ }^{10}$ Our sample is close to the Hong Kong 2006 Population By-Census in terms of education level (10 years of schooling on average) and income (median around HK\$17,000 per month). In Figure 2 we plot the number of investors in each Minibond series in our sample against the number of investors recorded by the Legislative Council of Hong Kong (LegCo). To have a broad coverage for the figure, we include all minibond investors surveyed although some did not provide complete information (hence cannot be used for our regressions and not included in the base sample). These two data series match well, although the average investor profile varies across products.

\footnotetext{
${ }^{9}$ We thank the referee for this point.

${ }^{10}$ http://www.bycensus2006.gov.hk/en/press/index.htm.
} 
We also note from untabulated analysis that the dollar amount matches less well than the number of investors, suggesting that our data is not biased towards certain types of investors (e.g., investors with biggest investments). Moreover, we interviewed 23 investors twice and their answers were identical in the two interviews. We acknowledge that we cannot completely rule out misreporting. Nevertheless, those results help mitigate our concerns on data representativeness and survey accuracy.

The instances of product suitability checks not being conducted before purchases comprise $52 \%$ of our sample transactions. We note that the structured product allocation and suitability check data are self-reported. The fact that $48 \%$ of the investors said that salespeople indeed checked the product suitability for their transactions suggests that misreporting of the suitability check, if any, is probably not systematic. Any idiosyncratic misreporting may add noise to our measurements and go against finding significant results. We also stress that the investment decision is multi-dimensional. Investors need to choose the currency, tenor and, most importantly, the exact amount in the offered products after the suitability check.

One caveat of our study is that our findings are conditional on participation in structured products. To give our main analysis a context, we explore participation in the structured product market using data for both investors and non-investors. As shown in Appendix Table A1, age, gender, and marital status are important determinants of structured product participation. Male investors are less likely to buy structured products. Moreover, married investors are more likely to buy structured products while high income earners are less likely to buy structured products. Therefore, married female individuals are most likely to participate in the structured product market in our sample. We also find that better educated investors in our sample are less likely to invest in structured products.

\section{Suitability Checks and Investment Allocation to Structured Products}


In this section, we first present our main findings on the relationship between suitability checks and structured product investments in a baseline regression. We then use the instrumental variable (IV) approach and propensity score matching approach to address the endogeneity concern in suitability checks. We further provide a robustness check on our main finding using an alternative sample. Potential mechanisms for the suitability check effect are discussed with the aid of financial literacy data. Lastly, we examine whether investor welfare is related to product suitability checks.

\subsection{Baseline Regression Results}

We report our ordinary least squares (OLS) regression results in Table 2. The dependent variable is the proportion of household investments in structured products relative to financial wealth. The key independent variable is the suitability check variable, Suitability Not Checked, which takes the value of one if product suitability is not checked before purchase and zero otherwise. Specification 1 shows a univariate relationship between the suitability check and investment without any control variables. Investors put $7.9 \%$ ( $p$-value $=0.028)$ more into structured products when product suitability is not checked. We add investor demographics such as age, gender, marital status, and household monthly income in specification 2 . The suitability check continues to be a significant explanatory variable, and the economic magnitude is not impacted much by the control variables. The coefficient estimate for the suitability check is $7.8 \%$ $(p$-value $=0.03)$. The only significant demographic explanatory variable for structured product investment is household income. Structured product investments decrease by $2.2 \%$ for every HK $\$ 10,000$ increase in household monthly income. One standard deviation change in monthly income $(\mathrm{HK} \$ 16,500)$ is associated with a change of $3.6 \%$ in structured product investments. This finding is consistent with a recent survey by SIFMA (2010) which finds that wealthier households own fewer structured products in the U.S. This structured product investment result 
is in contrast to the stylized fact that wealthier households are more likely to participate in financial markets and hold more stocks (see, e.g., Wachter and Yogo (2010)).

Investors may chase high-yield products. Specification 3 includes a control variable for the product coupon rate. Again, the effect of the suitability check remains significant with a coefficient estimate of $8.1 \%$ and $p$-value of 0.024 . The product coupon rate does not have a significant effect on structured product investment. ${ }^{11}$ Brand names of distributing banks might also influence investment decisions. If the banks have a good reputation, investors may implicitly trust products certified by their distributors and buy more. We use the logarithm of bank total assets to proxy for distributor reputation. Specification 4 shows that bank size is not related to product investment amount. The suitability check is still significant with similar magnitude and statistical significance after controlling for bank size. We also consider the potential effect of the market investment environment. Outside investment opportunities vary with the market interest rate and investors may simply put money in savings accounts when the interest rate is high. Using the Hong Kong Interbank Overnight Rate (Hibor) as a control variable, we find that structured products investment allocations are not significantly related to the market interest rate, as shown in specification 5. Moreover, the suitability check is still significant with this control variable. Therefore, the effect of the suitability check on structured products investment is robust to controls for other factors characterizing the transactions.

The magnitude of the suitability check effect ranges from $7.8 \%$ to $8.7 \%$. Given the average investment of $60.3 \%$ in structured products, $12.9 \%$ to $14.4 \%(7.8 \% / 60.3 \%, 8.7 \% / 60.3 \%)$ of the demand for structured product can be attributed to a lack of suitability checks. We stress that the suitability check is not the only determinant for structured product investment. The adjusted $R^{2}$ s in Table 2 are low. This result is consistent with the observation that the household

\footnotetext{
${ }^{11}$ When the coupon rate is too high, investors may be suspicious of products being low risk bonds. This consideration could offset investors' tendency to chase yield.
} 
investment portfolio is difficult to reconcile with standard theories (Campbell (2006)), although it is also possible that some omitted variables may affect the investment allocation to structured products. Nevertheless, the stand-alone $R^{2}$ for the suitability check itself in specification 1 is comparable to the $R^{2} \mathrm{~s}$ in other specifications with control variables. The ratio between adjusted $R^{2}$ s in specification 1 and in specification 5 is 0.52 , suggesting that the suitability check accounts for more than half of total explained variations in investment allocation. Therefore, the suitability check has a strong explanatory power relative to other variables for investor demographics, product characteristics, distributor size, and market conditions.

\subsection{Endogeneity in the Suitability Check}

A concern in making causal inferences from our baseline result is that the suitability check may be endogenous. Why product suitability is checked for some transactions but not for other transactions may reflect the strategic choice of salespeople. Inderst and Ottaviani (2009) provide a model of suitability standards when salespeople are motivated by commissions and may sell unsuitable products to uninformed investors. The main prediction from their model is that product distributors may lower the suitability standard when the selling market is more competitive and when compliance costs are high. We use a logistic regression to explain the suitability check status. The dependent variable is the indicator for neglecting the suitability check ("Suitability Not Checked"). Supporting the prediction derived from the model of Inderst and Ottaviani (2009), salespeople are more likely to skip the suitability checks in a high interest rate environment or when more banks are selling the same product (our proxies for distribution competition), as shown in Appendix Table A2. Our findings indicate that salespeople at the distributing banks influence the likelihood of product suitability checks. With above understanding of suitability checks, we proceed to formally address the endogeneity concerns.

One form of endogeneity is the omitted variable problem. That is, some omitted variables may influence both whether salespeople conduct suitability checks and how much money 
investors allocate to structured products. Reverse causality is another possibility, as salespeople may skip suitability checks in order to sell more products as fast as possible. We use instrumental variable and propensity score matching approaches to address the endogeneity concerns, mainly the omitted variable issue, in this subsection. In later analysis on the mechanisms driving the relationship between the suitability check and structured product investment, we will make further inference on the causality. ${ }^{12}$

The choice of a proper suitability check is made by the salespeople. Therefore, we look for an instrument from the salespeople's information set. To satisfy the relevance condition, the instrument must be correlated with the suitability check. Moreover, the instrument can affect structured product investment only via the influence of the suitability check so that it can be excluded from investment decisions. We use the leverage status of the investors as the instrument variable (IV). The leverage position, that is, whether the investor owes money (other than mortgage) to the bank or elsewhere, is predetermined and exogenous to the structured product investment. Also, the source of capital should, at least in most theories, not affect the allocation of the capital. While it is possible in some hypothetical situation to associate leverage with portfolio risk, ${ }^{13}$ in our sample investors' allocations to stock and bonds are not different for leveraged and unleveraged investors as shown in Appendix Table A3, which also shows that leveraged and unleveraged investors are similar in other observable characteristics such as

\footnotetext{
${ }^{12}$ One aspect about the transaction procedure is worth mentioning. Several decisions are made after investors express interest in the products. The suitability check is a middle step. As multiple products are available from the same offerings, investors will need to choose the currency and tenor of the product they wish to invest in. Most importantly, the investment amount will be determined at the end. Salespeople may skip suitability check in order to sell more products. Therefore, it is plausible that the suitability check will affect the amount of investment (different from zero/one investment choice).

${ }^{13}$ We thank the referee for pointing out that investors can take more risk by either choosing riskier securities (when borrowing cost is high), or using leverage, or both.
} 
income and education. Therefore, it seems valid to exclude investor leverage from the investment allocation analysis.

Leverage is relevant to suitability checks in the following ways. First, the salespeople may take into account the fact that the credit department has already checked the financial condition of the investor when he borrows money from the bank. Therefore, the need for another check is smaller. Second, prior financial transaction experience such as debt financing may help qualify investors to buy structured products, making the pro-forma suitability check less necessary. Therefore, we expect a low chance of suitability checks for indebted investors.

Table 3 reports our two-stage least square (2SLS) estimation results using investor leverage status as an instrument for suitability checks. Investor leverage status is an indicator variable: it equals one if the investors have a loan from the distributing bank or elsewhere, and zero otherwise. The first column shows that investor leverage status is a valid instrument for suitability checks, as product suitability is less likely to be checked for leveraged investors. Investor leverage status is also the most significant explanatory variable for suitability checks, suggesting that it is not a weak IV.

The second column of Table 3 shows that investment allocation is still significantly related to the suitability check instrumented by investor leverage status. (We follow Cohen, Frazzinni, and Malloy (2012) to define the instrumented indicator variable to be one if the predicted probability is above one-half.) The coefficient estimate for the instrumented suitability check, 9.8\% ( $p$-value=0.032), is close to our baseline estimation result in Table 2. Our IV results support our original finding and are robust to this endogeneity control, although we acknowledge that we cannot completely eliminate the endogeneity concern using this approach.

As an alternative to the instrumental variable approach, we use the propensity score matching approach to further address the endogeneity concern on the suitability check. We first run a logistic regression to calculate the propensity scores of suitability checks for all investors 
based on their characteristics: age, gender, income, leverage status, coupon rate, bank size, and interest rate. We then pair each observation in the treatment group (Suitability Not Checked=1) with one observation from the control group (Suitability Not Checked=0). We note that the performance of the propensity score matching analysis depends on the matching between the treated and the control observations. Since we cannot exclude the possibility of some unobserved investor characteristic driving both suitability not checked and investment in structured products, the matching of treated and control group may be imperfect. Therefore, we use multiple matching criteria to attenuate the concern that our result is driven by a particular matching method.

Table 4 shows our propensity score matching results. In our first matching based on the nearest neighborhood, each observation from the treated group is matched to one or several observations from the control group whose propensity score is within the $1 \%$ radius distance. The result shows that, given the same probability of having suitability checked, the investors whose product suitability is not actually checked invest $10.6 \%$ more than those whose suitability is checked. Moreover, the result becomes stronger (the difference becomes $12.3 \%$ ) if we require more stringent matching (at the $0.5 \%$ radius distance). Our second matching method takes into account the fact that the matching variables could be correlated. Therefore, a Mahalanobis-metric matching is done and the result is similar to the radius matching. The last matching using semiparametric kernel matching circumvents the arbitrary choice for criteria and generates a similar result. Bootstrapped standard errors show that the differences are statistically significant using all four matching methods.

\subsection{Sampling Issue and Results from an Alternative Sample}

The finding that increased investments in structured products are associated with the suitability not being checked is conditional on participation as we only observe the status of suitability checks for completed transactions. It is possible that some investors decide not to buy 
structured products after the suitability check. Moreover, the effect of the suitability check may be strongest at the margin - when investors are choosing to invest or not. Our data does not allow us to directly test such issues. However, we argue that this data limitation implies that the actual relationship between the suitability check and structured product investments is probably even stronger for all investors. Specifically, if some investors decide not to buy any structured products (investment allocation $=0$ ) after the suitability check (suitability not checked $=0$ ), then such data, if we could observe it, would be consistent with and strengthen our findings of smaller investments associated with suitability checks. Therefore, this sampling problem will not damage our conclusion.

Another legitimate concern is on the representativeness of our sample, i.e., whether our data is a random draw from all structured product investors. Although our initial data diagnosis suggests that our base dataset is reasonably reliable, it is conceivable that some investors opt not to spend time on this matter when their investments are small, consequently they may not be in our sample. Nevertheless, even if investors with small investments do not enter our sample, we do not expect an opposite finding for those investors. In untabulated results, we find that the relationship between suitability checks and structured product investment is not statistically different for small and big investments. In another attempt to show the robustness of our main finding, we split our sample by survey time. The majority of our data are collected in March and May 2009. We find a consistently significant effect of the suitability check on structured product investments in sub-samples as shown in Appendix Table A4. We require complete information for all investors to enter our base sample. In Appendix Table A5, we allow different sample sizes for our regressions (so the first five specifications have 298 observations instead of 221) and find results are robust to sample choices. Moreover, we isolate investors who only made a single purchase in Appendix Table A6 and find significant result for this group of investors. 
We further address data concerns on sampling limitations using an alternative sample. We do not include this sample in our baseline regression analysis because product information is not available for those observations. Additionally, this alternative sample may be different from our base sample in terms of investor characteristics and products. Therefore, this alternative sample helps shed light on the generality of our main findings, although we acknowledge that this alternative sample is also subject to similar concerns as with our base sample.

Our alternative sample consists of 77 investors who also purchased structured products other than known CLNs. Recall that our main sample consists of two series of CLNs: Minibonds and Constellation notes. The drawback of this auxiliary sample is the lack of product information which is necessary to differentiate products. The major reason for the lack of product information is probably that the product is tailor-made specifically for the investors. Those products are mostly equity-linked notes or other equity-linked securities such as "accumulators" (a combination of calls and puts with knock-out triggers). There is no public information on them. However, we do have detailed information on investor background and transaction processes that allow us to redo the baseline analysis. Therefore, this auxiliary dataset provides another robustness check on whether our finding on the suitability check is specific to our main sample.

We regress the investment proportion in structured products on the suitability check indicator and other control variables using the alternative sample of 77 observations without product information. Regression results are reported in Table 5. Specification 1 shows a statistically and economically significant suitability check effect: investors allocate $16.4 \%(p$ value $=0.013$ ) more into structured products when salespeople do not conduct suitability checks for the investment. The stand-alone adjusted $R^{2}$ for the suitability check indicator is 0.067 . The effect of the suitability check is also robust to various controls in specifications 2 to 4. Suitability Not Checked accounts for about half of the explained variations in structured product investment in this sample from the comparison of adjusted $R^{2} \mathrm{~s}$ in specifications 1 and $4(0.067 / 0.136)$. 
Overall, the findings using this alternative, smaller sample are largely consistent with our baseline regression results using the main sample in Table 2. The magnitude of the suitability check effect from this alternative sample is comparable to the magnitude from the main sample.

\subsection{Understanding the Mechanisms}

The previous analyses show a robust finding that investors allocate about $8 \%$ more investments into structured products when salespeople do not conduct product suitability checks prior to the transaction. In this section, we explore the potential mechanisms of the suitability check effect. We find two plausible mechanisms: investor learning and salesperson's incentives. We use investor information accuracy and financial literacy to test these mechanisms. In our empirical design, we exploit potential cross-sectional variations in the effectiveness of investor learning and the salesperson's incentive mechanisms, as some investors are more prone to those influences than others.

Structured products are more complex than plain vanilla securities which individual investors understand reasonably well. Household investors may not have complete and correct knowledge of the structured products that they purchase. Therefore, learning can be an important element. The learning effect is consistent with the "neglected risks" theory of Gennaioli, Shleifer, and Vishny (2012). In their model, investors neglect the small-probability worst economic states and invest excessively in those structured products with a perceived low risk. This idea of neglecting bad states is similar to the conjecture that good states are over-weighted as described by Bernard, Boyle, and Gornall (2011). ${ }^{14}$

\footnotetext{
${ }^{14}$ The idea of neglected risk is related to the salience of risk and the suitability check is in the same spirit of reminder effect. Bertrand and Morse (2011) find that more evident disclosure of fees decreases the take-up of payday loans. Karlan, McConnell, Mullainathan, and Zinman (2011) show that reminders on future expenditures increase savings in their field experiments.
} 
The "neglected risks" model seems suitable to explain the observations of the Hong Kong structured product market. First, the model assumes that investors prefer safe cash flow. The structured products in our sample have constant coupon rates, which are the maximum returns that investors expect to receive from their investments, and they are mostly sold through banks targeting relatively older investors. Hence, many investors may conceive of those structured products as similar to bank deposits. The names of the products (e.g. "Minibond") may also induce investors to perceive them as riskless bonds. Second, the model assumes small probabilities for the worst scenarios. The products in our sample have payoffs linked to the bankruptcy of a basket of reference names which are well regarded by local people. Bankruptcies are low-probability events which individual investors may oftentimes be disposed to neglect. With complex products, household investors could be "bearing risk without recognizing that they are doing so" (Gennaioli, Shleifer, and Vishny (2012, page 454)). Third, the model assumes that investors focus on the good scenarios. The product brochures and prospectuses give examples that highlight the best scenarios at the front of the publication and worse scenarios further in. Consequently, the best scenarios are more salient and come first to the investor's mind, while the worse scenarios are easily overlooked.

Investors may learn about the product risk during the suitability check process and consequently may be less influenced by the neglected risks. Therefore, when product suitability is checked, investors are likely to buy fewer structured products. At a glance, our estimate on the magnitude of the suitability check effect is quantitatively consistent with the model prediction of Gennaioli, Shleifer, and Vishny (2012). ${ }^{15} \mathrm{We}$ also note that, in their model, neglected risk only explains part, not all, of investor demand for structured products.

\footnotetext{
${ }^{15}$ According to their model result, the excess demand for structured products due to neglect is the difference in returns between a downturn and a recession, adjusted by the risk-free rate. If we assume the return during a downturn to be $-5 \%$ and the return during a recession to be $-20 \%$, and the risk free rate to be $3 \%$, then the excess
} 
While some investors try to learn the products by themselves, most people completely rely on salespeople's interpretations. Individual investors purchase structured products through the distributing banks. The transactions are processed by face-to-face communications between the investor and bank salespeople who explain the product characteristics and the purchase process. One may be concerned that the suitability check itself does not really matter to investment allocation; instead, the salespeople exert substantial influence. In particular, the supply side may withhold suitability checks in order to complete bigger purchases. This gives rise to the possibility of reverse causality: salespeople want to sell more as soon as possible, but suitability checks may hinder sales; therefore, they find ways to skip them. Such selling incentives are modeled by Gabaix and Laibson (2006), Inderst and Ottaviani (2009), and Carlin (2009).

We cannot directly measure to what extent investors neglect risks, making it a challenge to test the "learning" mechanism. Therefore, our test is indirect and based on the conjecture that risks are more likely to be neglected when suitability checks are not specifically conducted. This is similar to the "out of sight, out of mind" idea of Barber, Odean, and Zheng (2005) for mutual fund investors. Nevertheless, we do have a useful piece of information that makes it feasible to test the learning effect. In our sample, many investors claim that the product features were not what they had thought at the time of purchase. For example, credit-linked notes are first-todefault products which will suffer losses when any of the linked names experience a credit event (the first event). However, some investors thought that they would have losses only if all linked names defaulted. Some investors blame the salespeople for this misunderstanding. In our sample with available data, 146 out of 206 investors (70.9\%) said that salespeople gave them the wrong

demand for structured products due to neglected risks is $[(-5 \%)-(-20 \%)] /(1+3 \%)=14.6 \%$. Given the average investment is $60.3 \%$ in structured products and the coefficient estimate on the suitability check is about $8 \%$, the demand attributable to the lack of a suitability check is about $8 \% / 60.3 \%=13.3 \%$ which is fairly close to $14.6 \%$. 
knowledge about product characteristics, while only 60 investors said that salespeople explained the product characteristics correctly. We find that the suitability check effect is significant and similar for both investors blaming mis-interpretation and not blaming mis-interpretation by salespeople (Appendix Table A7).

Prior studies show financial literacy increases financial market participation or the better use of financial services (e.g., Choi, Laibson, and Madrian (2010); van Rooij, Lusardi, and Alessie (2011), Andersen and Nielsen (2011), Cole, Sampson, and Zia (2011)). Investor sophistication can moderate the relationship between suitability checks and structured product investments. Henderson and Pearson (2011) conclude that "it is difficult to rationalize their purchases [of structured products] by informed rational investors". They suggest that investors' cognitive limitations may explain the demand for overpriced structured products. For instance, some investors may not correctly recall the suitability check status (due to unconscious memory manipulation). It is possible that salesperson's skipping the suitability check is correlated with investor financial literacy, because people with better financial literacy are arguably better at following portfolio optimization rules and are less influenced by other factors.

We expect the suitability check to have separate effects on structured product investments from financial literacy, as the suitability check is transaction-specific. Specifically, we hypothesize that financially literate investors are less susceptible to a salesperson's manipulation. Investors with higher financial literacy are more capable of making investment decisions by themselves. Suitability checks, as part of the transaction procedure, should affect them less.

We use education level and numeracy ability to measure financial literacy. ${ }^{16}$ Education and numeracy are the basic background of the investors and can only be obtained over a long period of time. The neglect of suitability checks may be affected by experience, decision support

\footnotetext{
${ }^{16}$ See van Rooij, Lusardi, and Alessie (2011) for a detailed discussion on financial literacy measures. Calvet, Campbell, and Sodini (2009) use investment mistakes to measure financial sophistication.
} 
and advising. We measure education by the level of education recorded in our survey (results are similar if we convert the level into number of years of education). The education indicator equals one if the investor has high school or above education and zero otherwise. Numeracy is measured by an interest rate compounding question which is typical in the literature. If the investor can answer the question correctly, we classify him or her as financially literate in the sense of financial numeracy.

We separate our sample by investor education and numeracy and run our baseline regression in each subsample. The left portion of Table 6 Panel A shows that the effect of the suitability check is significantly positive for investors with a low education but insignificant for the high education group. Those educated below high school level invest $12.2 \%(p$-value $=0.024)$ more in structured products when salespeople skip product suitability checks for their purchase. Structured products investment by highly educated investors can be better explained by the set of independent variables than investments by low education investors as seen from the comparison of the $R^{2}$ s $(0.10$ versus 0.04$)$ across education groups. For example, low education investors increase investments in structured products when their income is higher, in sharp contrast to the negative relationship for the high education group.

The suitability check effect in high versus low financial numeracy groups is presented in the right column of Table 6 Panel A. The effect of suitability checks is statistically significant for investors with lower financial numeracy (coefficient $9.2 \%$ and $p$-value $=0.035$ ). For high financial numeracy people, the effect of lacking suitability checks is marginal. The adjusted $R^{2}$ for the high (low) financial literacy group is 0.09 (zero). The results from the financial numeracy subsamples are largely consistent with the education subsample analysis results. Therefore, our financial literacy subsample results are consistent with our hypothesis that the influence of suitability checks is stronger for less financially literate investors. 
We conduct interaction analysis to show the statistical significance of the difference between financial literacy groups in Panel B of Table 6. In specifications 1 and 3, we find that the education difference is statistically significance. We also find that people with higher financial literacy buy fewer structured products, but the suitability check has a distinct effect on structured product investment. Suitability checks, education, and financial numeracy have a similar effect on structured product investments in terms of economic magnitude. Our finding is consistent with Carlin and Robinson (2012) in that decision support - the suitability check in our case - is an important complement to financial literacy.

\subsection{Suitability Checks and Investment Performance}

One important concern for policy makers and investors themselves is whether investors' welfare is adversely affected by not having product suitability checked. It is possible that the products are such good deals in terms of risk-return tradeoffs that suitability checks would not matter (investors could even benefit from buying more). This "yield chasing" hypothesis would predict an insignificant or positive relationship between neglecting suitability checks and riskadjusted return. On the other hand, it is also possible that the distributors intentionally skip suitability checks in order to unload hard-to-sell products with unattractive risk-adjusted returns. We highlight that structured products are zero-sum games between investors and issuers/arrangers; the investor's loss is the issuer's gain. Therefore, over-priced products are more profitable to issuers and likely distributors who receive more commissions under a profit sharing scheme. This "selling for profit" conjecture would imply a negative relationship between skipping suitability checks and product net value.

To test these hypotheses, we need a valuation model for the structured products. While a good valuation model of complicated structured products linked to credit risk by itself is worth a separate study (see Chen and Sopranzetti (2003) and Wu (2010) for valuation of basket default swaps and CLNs) like Henderson and Pearson (2011), we aim to provide a standard and tractable 
valuation approach. The industry norm for CLN valuation is the Gaussian Copula model. ${ }^{17}$ Our sample CLNs are all first-to-default products. Therefore, the key valuation factors are: (1) individual reference entities' default risk including probability of default (PD) and loss given default (LGD); (2) default correlation between reference entities; and (3) collateral losses as investors' capital is used to buy collateral assets.

Investors receive periodic coupon payments before maturity or credit events. Interim coupon interest is not accrued since the last coupon payment date as the prospectus states that "notes will cease to bear any interest from the Interest Payment Date immediately preceding the occurrence of a Credit Event or an underlying Securities Default Event." If a credit event occurs, then investors will lose money and the redemption amount is determined by the calculation agent. Collateral damage affects both investors and counterparties, but the investor is affected slightly more because the protection buyer has first claim of the collateral value, and investors are second in line. Investors have limited liabilities because when collateral asset value is insufficient to pay counterparties, CLN investors will not make up the difference. (Counterparty risk is irrelevant as investors, the CDS sellers, already put up the money upfront for full collateralization.) The total fair value of the CLN to investors is:

$$
\begin{gathered}
c \times \sum_{i=1}^{T} e^{-r t_{i}} \times I\left(t_{i}<\min \left(\tau^{c}, \tau^{1}\right)\right) \\
+\left(\delta^{c}-\varepsilon\right)^{+} \times e^{-r \tau^{c}} \times I\left(\tau^{c}<\min \left(\tau^{1}, t_{T}\right)\right) \\
+\left(\delta^{1}-\theta-\varepsilon\right)^{+} \times e^{-r \tau^{1}} \times I\left(\tau^{1} \leq \min \left(\tau^{c}, t_{T}\right)\right) \\
+e^{-r t_{T}} \times(1-\theta) \times I\left(t_{T}<\min \left(\tau^{c}, \tau^{1}\right)\right)
\end{gathered}
$$

where $c$ is the coupon rate, $t_{i}$ are dates for coupon payments, and $T$ is the product maturity date, $r$ is the risk-free discount rate, $I$ is the indicator function, $\tau^{1}$ is the reference entities' first default

\footnotetext{
${ }^{17}$ We thank the referee for this suggestion. In previous versions we used a parsimonious model to value CLN and found similar results.
} 
time and $\tau^{c}$ is the collateral credit event time, $\delta^{1}$ is the recovery rate of the first default reference entity and $\delta^{c}$ is the collateral asset recovery rate, $\varepsilon$ is the swap termination value adjustment, and $\theta$ the redemption handling cost. The notes were sold at par. Hence, the net value for investors is the difference between the fair value and the par offering price investors paid.

To implement the above valuation model, we first use the credit default swap (CDS) spread to get the market implied risk-neutral default probabilities RNDP $=$ CDS Spread/LGD. We find the CDS spread for each reference entity on the offering date from Bloomberg. We use CDS spreads that have the same maturity as the CLNs. ${ }^{18}$ The recovery rate, or LGD data, is from S\&P's CDO Evaluator which is the standard tool for practitioners.

We need correlation data for the Copula implementation. Given that default correlation is difficult to pin down, we consider two cases: one with zero default correlations and another with default correlations from the CDO Evaluator. We first simulate independent default time. We then use the Cholesky Decomposition and Gaussian Copula to generate correlated default time. We find negative net value for our entire sample of CLNs (mean=-5.4\%, $t$-stat $=-13.99) .{ }^{19}$ Our finding is broadly consistent with Henderson and Pearson (2011) on U.S. equity-linked structured products.

We regress the net value of the CLNs on the suitability check indicator and other control variables. Regression results are reported in Table 7. The structured products purchased without proper suitability checks have a significantly lower net value. This finding is robust to controls

\footnotetext{
${ }^{18} \mathrm{CDS}$ spreads are more common at 5-year maturity but our CLNs usually have different maturities. Linear interpolation is used when the exact CDS spread maturity is not available. If the CDS data is unavailable on the offering date, the CDS spread from the last observation is used. The CDS data of several reference entities are not available from Bloomberg, so we substitute the CDS of a matching firm from the same industry with similar size and leverage.

${ }^{19}$ We did not include collateral loss as we do not have collateral information for most of the CLNs. We do not expect a systematic variation in expected collateral loss that will give us the result that we find.
} 
for investor background, market conditions, and product characteristics. The economic magnitude is $-1.85 \%(p$-value $=0.051)$ with zero correlation and $-1.84 \%(p$-value $=0.045)$ with standard default correlation. Therefore, investors lose about $1.85 \%$ in their investments when salespeople do not conduct suitability checks for their purchases.

Alternative to the CDS-implied risk-neutral default probabilities for CLN valuation, we have also used actual default probability from rating history to calculate expected returns. We obtain the term structure of default probabilities from Standard and Poor's Annual Global Corporate Default Study (also in CDO Evaluator). We do not find a significant relationship between product expected return and the suitability check, suggesting that investors were not expecting different returns whether suitability was checked or not for the purchase. Therefore, the relationship between the net value and suitability check is not likely to be driven by investors going after different products associated with suitability checks.

The finding of lower risk-adjusted yield associated with suitability not checked is consistent with the "selling for profit" hypothesis but not consistent with the "yield chasing" hypothesis. Investors would be more likely to buy a product with a lower net value when suitability checks were not conducted. This evidence further supports the commission incentivized sales mechanism. Moreover, our evidence substantiates the mis-selling discussions of Inderst and Ottaviani (2009) that salespeople seek and advise clients based on the prospect of high commissions but sacrifice product suitability.

\section{Conclusion}

We use a unique dataset from Hong Kong to examine the effect of product suitability checks on household investments in unlisted structured products. We find that investors put about $8 \%$ more of their wealth into structured products when salespeople do not conduct product suitability checks before the purchase. Two plausible mechanisms consistent with this finding are investor learning during the suitability check process and salespeople skipping suitability 
checks in order to secure the commission. Our finding that the suitability check effect is more pronounced for less financially literate investors supports those mechanisms. Moreover, investors tend to buy products with lower risk-adjusted returns when product suitability is not checked for their purchases. Therefore, the suitability check has welfare implications for structured product investors. 


\section{References}

Andersen, Steffen, and Kasper Meisner Nielsen, 2011, Participation constraints in the stock market: Evidence from unexpected inheritance due to sudden death, Review of Financial Studies 24, 1667-1697.

Barber, Brad, Terry Odean, and Lu Zheng, 2005, Out of sight, out of mind: The effects of expenses on mutual fund flows, The Journal of Business 78, 2095-2120.

Benmelech, Efraim, and Tobias Moskowitz, 2010, The political economy of financial regulation:

Evidence from U.S. State Usury Laws in the 19th Century, Journal of Finance 65, 10291073.

Bergstresser, Daniel, 2008, The retail market for structured notes: Issuance patterns and performance, 1995-2008, Working paper, Harvard Business School.

Bernard, Carole, Phelim Boyle, and William Gornall, 2011, Locally capped investment products and the retail investor, Journal of Derivatives 18(4), 72-88.

Bertrand, Marianne, and Adair Morse, 2011, Information disclosure, cognitive biases, and payday borrowing, Journal of Finance 66, 1865-1893.

Calvet, Laurent E, John Y Campbell, Paolo Sodini, 2009, Measuring the financial sophistication of households, American Economic Review 99, 393-398.

Campbell, John Y., 2006, Household finance, Journal of Finance 61, 1553-1604.

Campbell, John, Howell Jackson, Brigitte Madrian, and Peter Tufano, 2011, Consumer financial protection, Journal of Economic Perspectives 25, 91-114.

Cao, H. Henry, Bing Han, David Hirshleifer, and Harold H. Zhang, 2011, Fear of The Unknown: The Effects of Familiarity on Financial Decisions, Review of Finance15, 173-206.

Carlin, Bruce I., 2009, Strategic price complexity in retail financial markets, Journal of Financial Economics, 91, 278-28. 
Carlin, Bruce I., and Simon Gervais, 2012, Legal protection in retail financial markets, Review of Corporate Finance Studies 1, 68-108.

Carlin, Bruce I., and David T. Robinson, 2012, Financial education and timely decision support: Lessons from junior achievement, American Economic Review 102(3), 305-308.

Chen, Ren-raw, and Ben Sopranzetti, 2003, The valuation of default-triggered credit derivatives, Journal of Financial and Quantitative Analysis 38, 359-382.

Choi, James J., David Laibson, and Brigitte C. Madrian, 2010, Why does the law of one price fail? An experiment on index mutual funds, Review of Financial Studies 23, 1405-1432.

Cohen, Lauren, Andrea Frazzini, and Christopher Malloy, 2012, Hiring cheerleaders: Board appointments of "independent" directors, Management Science 58, 1039-1058.

Cole, Shawn, Thomas Sampson, and Bilal Zia, 2011, Prices or Knowledge? What drives demand for financial services in emerging markets? Journal of Finance 66, 1933-1967.

Friedman, Milton, 1997, The real lesson of Hong Kong, National Review, December 31, 1997.

Gabaix, Xavier, and David Laibson, 2006, Shrouded attributes, consumer myopia, and information suppression in competitive markets, Quarterly Journal of Economics 121, 505540.

Gennaioli, Nicola, Andrei Shleifer, and Robert Vishny, 2012, Neglected risks, financial innovation, and financial fragility, Journal of Financial Economics 104, 452-468.

Henderson, Brian J., and Neil D. Pearson, 2011, The dark side of financial innovation: A case study of the pricing of a retail financial product, Journal of Financial Economics 100, 227247.

Inderst, Roman, and Marco Ottaviani, 2009, Misselling through Agents, American Economic Review 99, 883-908.

Inderst, Roman, and Marco Ottaviani, 2012, How (not) to pay for advice: A framework for consumer financial protection, Journal of Financial Economics 105, 393-411. 
Karlan, Dean, Margaret McConnell, Sendhil Mullainathan, and Jonathan Zinman, 2011, Getting to the top of mind: How reminders increase saving, Working paper.

Lee, Joseph, and Veronica Chang, 2005, A survey on the retail structured notes market in Hong Kong, Hong Kong SFC Research Paper No. 24.

Lee, Joseph, and Veronica Chang, 2006, The retail structured notes market in Hong Kong amid a rate hike cycle, Hong Kong SFC Research Paper No. 34.

Li, Gang, and Chu Zhang, 2011, Why are derivative warrants more expensive than options? An empirical study, Journal of Financial and Quantitative Analysis 46, 275-297.

SEC, 2011, Staff summary report on issues identified in examination of certain structured securities products sold to retail investors.

SIFMA, 2010, Standard of care harmonization: Impact assessment for SEC.

Stoimenov, Pavel A., and Sascha Wilkens, 2005, Are structured products fairly priced? An analysis of the German market for equity-linked instruments, Journal of Banking and Finance 29, 2971-2993.

Tufano, Peter, 2009, Consumer finance, Annual Review of Financial Economics 1, 227- 247.

van Rooij, Maarten, Annamaria Lusardi, and Rob Alessie, 2011, Financial literacy and stock market participation, Journal of Financial Economics 101, 449-472.

Wachter, Jessica A., Motohiro Yogo, 2010, Why do household portfolio shares rise in wealth?, Review of Financial Studies 23, 3929-3956.

Wasik, John F, 2011, How complex derivative products imperil seniors' retirement security, Research report from Demos and the Nation Institute.

Wu, Po-Cheng, 2010, Applying a factor copula to value basket credit linked notes with issuer default risk, Finance Research Letters 7, 178-183. 


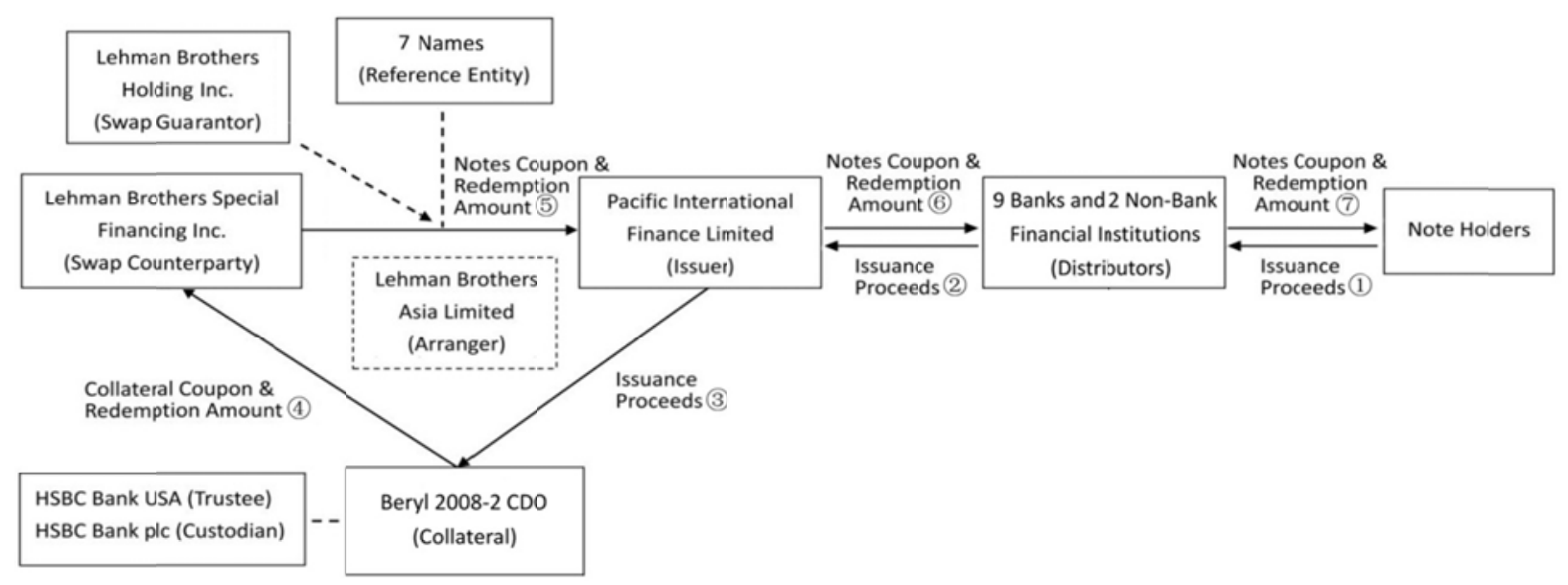

Reference Entity: HSBC Bark PLC (Aa2/AA-), Hutchison WhampoaLimited (A3/A-), MTR Corporation Limted (Aa2/AA), the People's Republic of China (PRC) (A1/A), Standard Chartered Bank (A3/A), Sun Hung Kai Properties Limited (A1/A) and Swire Pacific Lim ited (A3/A-).

Distributors: Public Bank (Hong Kong); ABN AMRO Bank N.V.; Bank of China (Hong Kong); Chiyu Banking Corporation; Wing Lung Bank Limited; Chong Hing Bank Limited; Dah Sing Bank; KGI Asia Limited; MEVAS Bank Limited; Nanyang Commercial Bank; Sun Hung Kai Investment Services.

Figure 1. Illustrative Example of the Structure of Credit-Linked Notes. This figure shows the structure of a credit-linked notes Minibond Series 35. The names of the seven reference entities of Minibond Series 35 are reported at the bottom of the figure. The credit ratings shown next to each reference entity are those applicable to the reference obligation as on 11 January 2008 by Moody's Investors Service and Standard \& Poor's. 


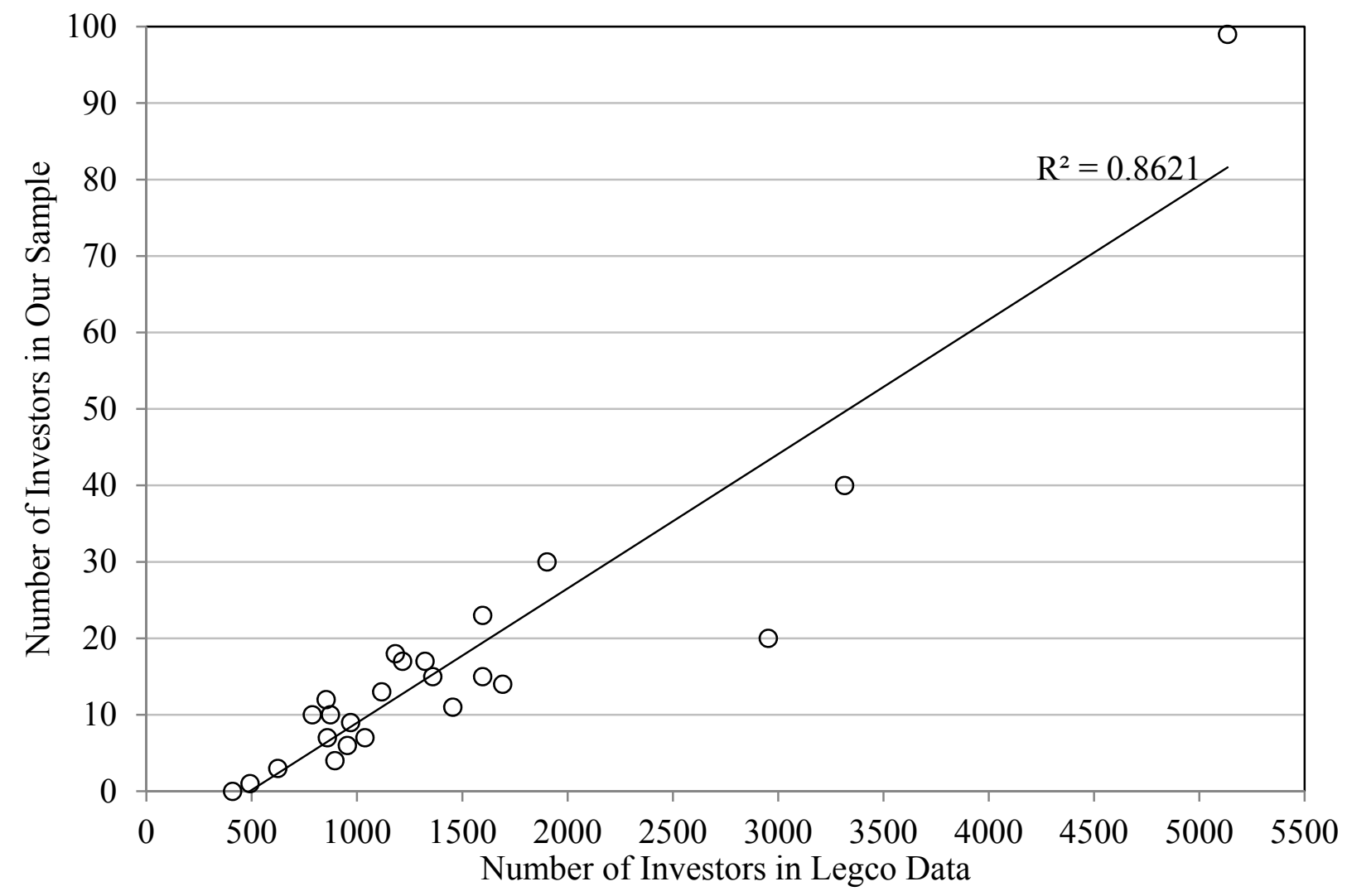

Figure 2. Sample Comparison for Minibond Data. This figure plots the number of investors for the Minibond credit-linked notes in our surveys versus the number of investors in the Legislative Council of Hong Kong (LegCo) record. Each dot represents one series of the Minibond notes. 


\section{Table 1 \\ Summary Statistics of Structured Products Investment Data}

This table summarizes our data. Our sample includes information about 221 investors in two best selling credit-linked notes (CLNs) in Hong Kong issued during 2003-2008: Minibond and Constellation notes. Investor demographics and transaction data are obtained through face-to-face interviews conducted from January to June 2009. Data on the two structured products are obtained from the issuing prospectuses available on the website of Hong Kong Securities and Futures Commission (SFC). Proportion in structured products (\%) is the percentage of investment in structured products to total financial wealth. Suitability not checked is a dummy variable and equals one if the investor did not take suitability check for purchasing structured products before investing, and zero if took. Leveraged investment is an indicator for whether the investor is in debt while investing in the product. Reference entity CDS coverage (\%) measures how many names in the product's reference entity had CDS trading in the year when the structured product was issued. Bank size is the logarithm of the total asset value of the distributing bank from which the investor purchased the structured product. Interest rate is measured by 1-year Hong Kong Interbank Offered Rates (HIBOR) at the issuing month. Blaming misinterpretation is a dummy variable and equals one if the investor alleged that salesperson incorrectly provided information or did not provide information regarding the payoff structure of structured products, and zero otherwise.

\begin{tabular}{|c|c|c|c|}
\hline Variables & Mean & Median & Standard Deviation \\
\hline \multicolumn{4}{|l|}{ Investment decision } \\
\hline Proportion in structured products (\%) & 60.34 & 65.00 & 26.74 \\
\hline Amount in structured products (\$million HKD) & 0.78 & 0.50 & 1.04 \\
\hline Suitability not checked & 0.52 & 1 & 0.50 \\
\hline \multicolumn{4}{|l|}{ Backgrounds of household investors } \\
\hline Age & 55.18 & 58 & 9.19 \\
\hline Male & 0.35 & 0 & 0.48 \\
\hline Married & 0.90 & 1 & 0.30 \\
\hline Income (Monthly by $\$ 1,000 \mathrm{HKD}$ ) & 15.40 & 10.10 & 16.58 \\
\hline Leveraged Investment & 0.11 & 0 & 0.26 \\
\hline \multicolumn{4}{|l|}{ Financial literacy and education of household investors } \\
\hline Enrolled in high school & 0.51 & 1 & 0.50 \\
\hline Can calculate compound interest rate & 0.30 & 0 & 0.46 \\
\hline \multicolumn{4}{|l|}{ Product characteristics } \\
\hline Annual coupon rate $(\%)$ & 5.26 & 5.60 & 1.00 \\
\hline Number of reference entities & 6.72 & 7.00 & 1.29 \\
\hline Number of distributing banks & 11.90 & 13 & 2.31 \\
\hline \multicolumn{4}{|l|}{ Transaction details } \\
\hline Bank size & 5.51 & 5.90 & 0.56 \\
\hline Interest rate (HIBOR) on issuing date (\%) & 2.73 & 2.84 & 1.34 \\
\hline Blaming misinterpretation & 0.71 & 1 & 0.46 \\
\hline
\end{tabular}




\section{Table 2 \\ Suitability Checks and Investments in Structured Products}

This table presents OLS regression results showing the effect of suitability check on investments in structured products.

The dependent variable is Investment Proportion in Structured Products (\%), which measures the proportion of total financial wealth invested in structured products at the time of investment. The independent variables include an indicator for not taking suitability check before investing in structured products, Suitability not checked, and control variables including investor demographics and financial background. The $p$-values are in parentheses.

\begin{tabular}{|c|c|c|c|c|c|}
\hline \multirow{2}{*}{$\begin{array}{l}\text { Independent } \\
\text { Variables: }\end{array}$} & \multicolumn{5}{|c|}{ Dependent Variable: Investment Proportion in Structured Products (\%) } \\
\hline & $(1)$ & $(2)$ & $(3)$ & $(4)$ & $(5)$ \\
\hline Suitability not checked & $\begin{array}{c}7.904 \\
(0.028)\end{array}$ & $\begin{array}{c}7.765 \\
(0.030)\end{array}$ & $\begin{array}{l}8.050 \\
(0.024)\end{array}$ & $\begin{array}{c}8.155 \\
(0.023)\end{array}$ & $\begin{array}{c}8.662 \\
(0.017)\end{array}$ \\
\hline Age & & $\begin{array}{c}-0.088 \\
(0.653)\end{array}$ & $\begin{array}{c}-0.095 \\
(0.629)\end{array}$ & $\begin{array}{c}-0.091 \\
(0.645)\end{array}$ & $\begin{array}{c}-0.097 \\
(0.622)\end{array}$ \\
\hline Male & & $\begin{array}{c}-4.694 \\
(0.218)\end{array}$ & $\begin{array}{c}-4.720 \\
(0.215)\end{array}$ & $\begin{array}{c}-4.652 \\
(0.223)\end{array}$ & $\begin{array}{c}-4.817 \\
(0.207)\end{array}$ \\
\hline Married & & $\begin{array}{c}-0.586 \\
(0.922)\end{array}$ & $\begin{array}{c}0.040 \\
(0.995)\end{array}$ & $\begin{array}{c}0.177 \\
(0.977)\end{array}$ & $\begin{array}{c}0.376 \\
(0.950)\end{array}$ \\
\hline Income & & $\begin{array}{c}-0.240 \\
(0.027)\end{array}$ & $\begin{array}{c}-0.255 \\
(0.019)\end{array}$ & $\begin{array}{c}-0.249 \\
(0.024)\end{array}$ & $\begin{array}{c}-0.262 \\
(0.018)\end{array}$ \\
\hline Annual coupon rate & & & $\begin{array}{c}-2.318 \\
(0.197)\end{array}$ & $\begin{array}{c}-2.360 \\
(0.190)\end{array}$ & $\begin{array}{c}-1.789 \\
(0.335)\end{array}$ \\
\hline Bank size & & & & $\begin{array}{c}-1.335 \\
(0.678)\end{array}$ & $\begin{array}{c}-1.242 \\
(0.700)\end{array}$ \\
\hline Interest rate (HIBOR) & & & & & $\begin{array}{c}-1.708 \\
(0.222)\end{array}$ \\
\hline Constant & $\begin{array}{l}56.226 \\
(0.000)\end{array}$ & $\begin{array}{l}67.027 \\
(0.000)\end{array}$ & $\begin{array}{l}79.100 \\
(0.000)\end{array}$ & $\begin{array}{l}86.175 \\
(0.000)\end{array}$ & $\begin{array}{c}87.461 \\
(0.000)\end{array}$ \\
\hline Observations & 221 & 221 & 221 & 221 & 221 \\
\hline Adjusted $R^{2}$ & 0.017 & 0.031 & 0.034 & 0.030 & 0.033 \\
\hline
\end{tabular}




\section{Table 3 \\ Suitability Checks and Investments in Structured Products: Instrumental Variable Approach}

This table presents two-stage estimation results using Leveraged investment as a instrumental variable for Suitability not checked. The first stage is a probit regression with Suitability not checked as the dependent variable. The dependent variable for the second stage is the Investment Proportion in Structured Products (\%). Instrumented suitability not checked equals one if the predicted value in the first stage is above 0.5. The $p$-values are in parentheses.

\begin{tabular}{lcc}
\hline & $\begin{array}{c}\text { Suitability Not Checked } \\
\text { (Stage 1: Probit) }\end{array}$ & $\begin{array}{c}\text { Investment Proportion }(\%) \\
\text { (Stage 2: OLS) }\end{array}$ \\
\hline Instrumented suitability not checked & & 9.834 \\
& & $(0.032)$ \\
Leveraged investment & 0.758 & \\
Age & $(0.033)$ & -0.158 \\
& 0.002 & $(0.427)$ \\
Male & $(0.864)$ & -1.492 \\
& -0.064 & $(0.719)$ \\
Married & $(0.721)$ & 3.574 \\
& -0.119 & $(0.569)$ \\
Income & $(0.676)$ & -0.269 \\
& 0.000 & $(0.014)$ \\
Annual coupon rate & $(0.968)$ & -3.905 \\
& 0.035 & $(0.050)$ \\
Constant & $(0.679)$ & 84.729 \\
& -0.151 & $(0.000)$ \\
Observations & $(0.835)$ & 221 \\
Pseudo/Adjusted $R^{2}$ & 221 & 0.032 \\
\hline
\end{tabular}




\section{Table 4 \\ Suitability Checks and Investments in Structured Products: Propensity Score Matching Approach}

This table shows the comparison between structured product investments with matched propensity score of suitability check. Propensity scores of suitability check are obtained from a Logit regression of Suitability not checked on Age, Male, Married, Income, Levered, Annual coupon rate, Bank size, and Interest Rate (HIBOR). Each observation without suitability check (the treated group) is matched to one or more observations with same propensity score of suitability check but with actual suitability check (the control group). Four matching criteria are used. Radius 1\% (0.5\%) Matched matches each transaction from the treated group to one or more transactions from the control group if the difference between their propensity scores of no suitability check is less than $1 \%(0.5 \%)$. Mahal. Distance Matched performs the Mahalanobis-metric matching, which accounts for the correlation of investor background variables. Epan. Kernel Matched uses the bias-variance-optimal Epanechnikov kernel to do the matching semi-parametrically. Reported are the average investment allocation from those groups. The standard errors for the matched samples are the bootstrapped standard errors with 1000 draws. The $p$-values are in parentheses.

\begin{tabular}{lrrrrrrr}
\hline Sample & Treated & Controls & Difference & $\begin{array}{c}\text { S.E. } \\
\text { (Bootstrap) }\end{array}$ & Z-stat. & \multicolumn{2}{c}{ Matching in Treated Group } \\
\cline { 5 - 8 } & & & & & Matched Obs. & Total Obs. \\
\hline Radius 1\% Matched & 64.190 & 53.578 & 10.612 & 4.871 & 2.179 & 105 & 115 \\
Radius 0.5\% Matched & 63.182 & 50.924 & 12.258 & 5.459 & 2.245 & 99 & 115 \\
Mahal. Distance Matched & 64.130 & 52.826 & 11.304 & 5.780 & 1.956 & 115 & 115 \\
Epan. Kernel Matched & 64.130 & 54.412 & 9.719 & 4.045 & 2.403 & 115 & 115 \\
\hline
\end{tabular}




\section{Table 5 \\ Suitability Checks and Investments in Structured Products: Results from an Alternative Sample}

This table shows OLS regression results for the suitability check effect on investment decisions using an alternative sample of investments in structured products. This alternative sample consists of 77 investors who provided all information but product names. Therefore, product characteristics are unknown. The dependent variable is the investment proportion in structured products. The $p$-values are in parentheses.

\begin{tabular}{|c|c|c|c|c|}
\hline \multirow{2}{*}{$\begin{array}{l}\text { Independent } \\
\text { Variables: }\end{array}$} & \multicolumn{4}{|c|}{ Dependent Variable: Investment Proportion in Structured Products (\%) } \\
\hline & (1) & $(2)$ & $(3)$ & $(4)$ \\
\hline Suitability not checked & $\begin{array}{c}16.439 \\
(0.013)\end{array}$ & $\begin{array}{c}19.986 \\
(0.003)\end{array}$ & $\begin{array}{c}20.701 \\
(0.002)\end{array}$ & $\begin{array}{l}20.691 \\
(0.002)\end{array}$ \\
\hline Age & & $\begin{array}{c}-0.328 \\
(0.328)\end{array}$ & $\begin{array}{c}-0.253 \\
(0.464)\end{array}$ & $\begin{array}{r}-0.244 \\
(0.477)\end{array}$ \\
\hline Male & & $\begin{array}{c}0.361 \\
(0.957)\end{array}$ & $\begin{array}{c}-0.911 \\
(0.895)\end{array}$ & $\begin{array}{c}-2.644 \\
(0.704)\end{array}$ \\
\hline Married & & $\begin{array}{c}-1.720 \\
(0.859)\end{array}$ & $\begin{array}{c}-2.026 \\
(0.835)\end{array}$ & $\begin{array}{c}-3.348 \\
(0.731)\end{array}$ \\
\hline Income & & $\begin{array}{c}-0.413 \\
(0.006)\end{array}$ & $\begin{array}{c}-0.409 \\
(0.006)\end{array}$ & $\begin{array}{r}-0.434 \\
(0.004)\end{array}$ \\
\hline Bank size & & & $\begin{array}{c}-7.184 \\
(0.359)\end{array}$ & $\begin{array}{r}-6.731 \\
(0.388)\end{array}$ \\
\hline Interest rate $(\mathrm{HIBOR})$ & & & & $\begin{array}{c}-3.562 \\
(0.184)\end{array}$ \\
\hline Constant & $\begin{array}{l}48.788 \\
(0.000) \\
\end{array}$ & $\begin{array}{l}75.285 \\
(0.000) \\
\end{array}$ & $\begin{array}{c}109.608 \\
(0.011) \\
\end{array}$ & $\begin{array}{c}119.931 \\
(0.006) \\
\end{array}$ \\
\hline Observations & 77 & 77 & 77 & 77 \\
\hline Adjusted $R^{2}$ & 0.067 & 0.128 & 0.126 & 0.136 \\
\hline
\end{tabular}




\section{Table 6 \\ Suitability Checks and Investments in Structured Products: The Role of Investor Financial Literacy}

This table presents OLS regression results on the suitability check effect while controlling for investor financial literacy. The dependent variable is investment proportion in structured products. Panel A shows estimation results using subsamples divided by investor financial literacy. Panel B includes interaction terms between suitability not checked and financial literacy (other control variables are compressed to conserve space). Financial literacy is proxied by education and numeracy. Enrolled in high school, the measure of education, is a dummy variable that equals one if the investor has high school or above education. Can calculate compound interest rate, the measure for numeracy, is a dummy variable and equals one if the investor correctly answered the question regarding the calculation of compounding interest rate. The question is: "Imagine you save HKD10,000 in a bank today and the interest rate for bank deposit is $10 \%$ every year. How much would you get after two years of saving in the bank? (A) HKD10,000 (B) HKD10,00111,000 (C) HKD11,001-12,000 (D) $\geq$ HKD12,001". The correct answer for this question is D. The $p$-values are in parentheses. 
Table 6 - Continued

Suitability Checks and Investments in Structured Products: The Role of Investor Financial Literacy

\begin{tabular}{|c|c|c|c|c|}
\hline & & anel A: Subsample & & \\
\hline Independent & Dep & Variable: Investm & on in Structur & $(\%)$ \\
\hline Variables: & Enro & High School & Can Calculat & Interest Rate \\
\hline Suitability not checked & $\begin{array}{c}4.032 \\
(0.384)\end{array}$ & $\begin{array}{l}12.242 \\
(0.024)\end{array}$ & $\begin{array}{l}11.314 \\
(0.088)\end{array}$ & $\begin{array}{c}9.198 \\
(0.035)\end{array}$ \\
\hline Male & $\begin{array}{r}-4.035 \\
(0.398)\end{array}$ & $\begin{array}{l}-2.322 \\
(0.688)\end{array}$ & $\begin{array}{r}-8.542 \\
(0.204)\end{array}$ & $\begin{array}{r}-2.402 \\
(0.603)\end{array}$ \\
\hline Married & $\begin{array}{r}-0.608 \\
(0.944)\end{array}$ & $\begin{array}{c}-0.051 \\
(0.995)\end{array}$ & $\begin{array}{l}19.871 \\
(0.154)\end{array}$ & $\begin{array}{r}-3.734 \\
(0.582)\end{array}$ \\
\hline Bank size & $\begin{array}{r}-1.296 \\
(0.754)\end{array}$ & $\begin{array}{l}-3.408 \\
(0.484)\end{array}$ & $\begin{array}{l}-1.204 \\
(0.857)\end{array}$ & $\begin{array}{r}-2.677 \\
(0.468)\end{array}$ \\
\hline Interest rate (HIBOR) & $\begin{array}{r}-3.181 \\
(0.065)\end{array}$ & $\begin{array}{c}1.918 \\
(0.385)\end{array}$ & $\begin{array}{r}-0.809 \\
(0.746)\end{array}$ & $\begin{array}{r}-1.299 \\
(0.446)\end{array}$ \\
\hline Constant & $\begin{array}{r}104.067 \\
(0.001)\end{array}$ & $\begin{array}{l}70.963 \\
(0.044)\end{array}$ & $\begin{array}{l}94.911 \\
(0.057)\end{array}$ & $\begin{array}{l}88.887 \\
(0.001)\end{array}$ \\
\hline $\begin{array}{l}\text { Observations } \\
\text { Adjusted } R^{2}\end{array}$ & $\begin{array}{l}113 \\
0.111\end{array}$ & $\begin{array}{l}108 \\
0.050\end{array}$ & $\begin{array}{l}66 \\
0.098\end{array}$ & $\begin{array}{l}155 \\
-0.010\end{array}$ \\
\hline $\begin{array}{l}\text { Suitability not checked } \\
\times \text { Enrolled in high }\end{array}$ & & $\begin{array}{r}-14.957 \\
(0.004)\end{array}$ & & $\begin{array}{r}-13.319 \\
(0.012)\end{array}$ \\
\hline $\begin{array}{l}\text { Suitability not checked } \\
\times \text { Can calculate con }\end{array}$ & terest rate & & $\begin{array}{r}-10.404 \\
(0.056)\end{array}$ & $\begin{array}{r}-7.022 \\
(0.203)\end{array}$ \\
\hline Constant & & $\begin{array}{l}93.170 \\
(0.000)\end{array}$ & $\begin{array}{l}88.452 \\
(0.000)\end{array}$ & $\begin{array}{l}93.214 \\
(0.000)\end{array}$ \\
\hline Control for household b & & Yes & Yes & Yes \\
\hline Control for transaction & & Yes & Yes & Yes \\
\hline Observations & & 221 & 221 & 221 \\
\hline Adjusted $R^{2}$ & & 0.066 & 0.045 & 0.068 \\
\hline
\end{tabular}


Table 7

\section{Suitability Checks and Valuation of Chosen Products}

This table reports OLS regression results on the suitability check effect on the value of chosen structured products. The dependent variable is the net value of structured products calculated by the Copula-based Monte Carlo simulation method described in subsection 3.5. Initial inputs are the credit default swap (CDS) spreads of the reference entities. Default correlations are assumed to be zero for the first column and according to the data in the S\&P CDO Evaluator 4.0 for the second column. The $p$-values are in parentheses.

\begin{tabular}{lcc}
\hline Independent & \multicolumn{2}{c}{ Dependent Variable: Net Value of Structured Product } \\
\cline { 2 - 3 } Variables: & Zero Default Correlation & S\&P Default Correlation \\
\hline Suitability not checked & -1.850 & -1.843 \\
& $(0.051)$ & $(0.045)$ \\
Age & 0.007 & 0.008 \\
& $(0.904)$ & $(0.891)$ \\
Male & -0.338 & -0.266 \\
& $(0.777)$ & $(0.817)$ \\
Married & 1.394 & 1.313 \\
& $(0.461)$ & $(0.470)$ \\
Income & 0.014 & 0.017 \\
& $(0.683)$ & $(0.616)$ \\
Annual coupon rate & -0.540 & -0.315 \\
& $(0.354)$ & $(0.574)$ \\
Bank size & -1.967 & -1.982 \\
& $(0.052)$ & $(0.042)$ \\
Interest rate (HIBOR) & 3.538 & 3.520 \\
& $(0.000)$ & $(0.000)$ \\
Constant & -10.506 & -11.101 \\
& $(0.146)$ & $(0.110)$ \\
\hline Observations & 221 & 221 \\
Adjusted $R^{2}$ & 0.227 & 0.244 \\
\hline
\end{tabular}




\section{Additional Tables for Reference (not for publication)}

\section{Table A1 \\ Participation in Structured Product Market}

This table demonstrates the determinants of investor participation in the structured product market. We run Probit regressions. The dependent variable is a dummy variable indicating structured product purchase (one for market participants and zero for non-participants). The sample consists of 338 participants and 50 non-participants. Data on non-participants are collected through face-to-face interviews at randomly chosen public locations in Hong Kong in July 2009. Data on the participants are collected through face-to-face interviews at various occasions between January and June 2009. The $p$-values are in parentheses.

\begin{tabular}{lcccc}
\hline Independent & \multicolumn{3}{c}{ Dependent Variable: Participating in Structured Product Market } \\
\cline { 2 - 4 } Variables: & $(1)$ & $(2)$ & $(3)$ & $(4)$ \\
\hline Age & 0.019 & 0.022 & 0.013 & 0.017 \\
& $(0.025)$ & $(0.010)$ & $(0.125)$ & $(0.066)$ \\
Male & -0.816 & -0.802 & -0.820 & $(0.000)$ \\
& $(0.000)$ & $(0.000)$ & $(0.000)$ & 0.580 \\
Married & 0.528 & 0.538 & 0.561 & $(0.017)$ \\
& $(0.025)$ & $(0.026)$ & $(0.018)$ & -0.008 \\
Income & -0.008 & -0.010 & -0.006 & $(0.040)$ \\
& $(0.036)$ & $(0.014)$ & $(0.102)$ & 0.624 \\
Leveraged & & 0.586 & & $(0.082)$ \\
& & $(0.098)$ & -0.405 & $(0.062)$ \\
Enroll in high school & & & $(0.054)$ & 0.526 \\
& & & 0.762 & $(0.332)$ \\
Constant & 0.266 & 0.028 & $(0.147)$ & 369 \\
& $(0.558)$ & $(0.952)$ & 387 & 0.152 \\
\hline Observations & 388 & 370 & 0.140 & \\
Pseudo $R^{2}$ & 0.127 & 0.140 & &
\end{tabular}




\section{Table A2 \\ The Determinants of Neglecting Product Suitability Checks}

This table shows Probit regression results. The dependent variable is the probability of suitability not checked. Suitability not checked is a dummy variable and equals one if product suitability was not checked before the purchase, and zero otherwise. The $p$-values are in parentheses.

\begin{tabular}{|c|c|c|c|c|}
\hline \multirow{2}{*}{$\begin{array}{l}\text { Independent } \\
\text { Variables: }\end{array}$} & \multicolumn{4}{|c|}{ Dependent Variable: Suitability Not Checked } \\
\hline & (1) & $(2)$ & $(3)$ & $(4)$ \\
\hline Interest rate (HIBOR) & $\begin{array}{c}0.184 \\
(0.007)\end{array}$ & & & $\begin{array}{c}0.160 \\
(0.031)\end{array}$ \\
\hline Annual coupon rate & & $\begin{array}{c}0.067 \\
(0.446)\end{array}$ & & $\begin{array}{c}-0.020 \\
(0.830)\end{array}$ \\
\hline Number of distributing banks & & & $\begin{array}{c}0.079 \\
(0.041)\end{array}$ & $\begin{array}{c}0.052 \\
(0.208)\end{array}$ \\
\hline Socially connected & $\begin{array}{c}-0.577 \\
(0.003)\end{array}$ & $\begin{array}{c}-0.497 \\
(0.009)\end{array}$ & $\begin{array}{c}-0.502 \\
(0.009)\end{array}$ & $\begin{array}{r}-0.569 \\
(0.004)\end{array}$ \\
\hline Levered & $\begin{array}{l}1.032 \\
(0.007)\end{array}$ & $\begin{array}{c}0.844 \\
(0.022)\end{array}$ & $\begin{array}{c}0.877 \\
(0.020)\end{array}$ & $\begin{array}{c}1.027 \\
(0.009)\end{array}$ \\
\hline Above high school $=0$ & $\begin{array}{c}0.326 \\
(0.078)\end{array}$ & $\begin{array}{c}0.285 \\
(0.117)\end{array}$ & $\begin{array}{c}0.300 \\
(0.100)\end{array}$ & $\begin{array}{c}0.334 \\
(0.072)\end{array}$ \\
\hline Investment amount (million HKD) & $\begin{array}{c}0.015 \\
(0.857)\end{array}$ & $\begin{array}{c}0.026 \\
(0.758)\end{array}$ & $\begin{array}{c}0.014 \\
(0.869)\end{array}$ & $\begin{array}{r}0.010 \\
(0.904)\end{array}$ \\
\hline $\ln ($ Age $)$ & $\begin{array}{c}-0.023 \\
(0.964)\end{array}$ & $\begin{array}{c}-0.039 \\
(0.938)\end{array}$ & $\begin{array}{c}0.038 \\
(0.941)\end{array}$ & $\begin{array}{c}0.023 \\
(0.964)\end{array}$ \\
\hline Male & $\begin{array}{c}-0.134 \\
(0.479)\end{array}$ & $\begin{array}{c}-0.145 \\
(0.440)\end{array}$ & $\begin{array}{r}-0.111 \\
(0.558)\end{array}$ & $\begin{array}{c}-0.112 \\
(0.555)\end{array}$ \\
\hline Married & $\begin{array}{c}-0.036 \\
(0.902)\end{array}$ & $\begin{array}{c}-0.039 \\
(0.896)\end{array}$ & $\begin{array}{c}-0.082 \\
(0.783)\end{array}$ & $\begin{array}{r}-0.069 \\
(0.817)\end{array}$ \\
\hline $\ln ($ Income $)$ & $\begin{array}{c}0.005 \\
(0.821)\end{array}$ & $\begin{array}{c}0.009 \\
(0.648)\end{array}$ & $\begin{array}{c}0.006 \\
(0.770)\end{array}$ & $\begin{array}{c}0.003 \\
(0.878)\end{array}$ \\
\hline Constant & $\begin{array}{c}-0.383 \\
(0.852)\end{array}$ & $\begin{array}{c}-0.201 \\
(0.923)\end{array}$ & $\begin{array}{c}-1.042 \\
(0.624)\end{array}$ & $\begin{array}{r}-0.986 \\
(0.649)\end{array}$ \\
\hline Observations & 221 & 221 & 221 & 221 \\
\hline Pseudo $R^{2}$ & 0.079 & 0.056 & 0.068 & 0.084 \\
\hline
\end{tabular}




\section{Table A3 \\ Comparison of Leveraged and Unleveraged Investors}

This table compares the characteristics of structured product investors who are leveraged versus those who are not leveraged. Leveraged investors are investors who owe money while buying structured products.

\begin{tabular}{|c|c|c|c|c|c|}
\hline & All & Leveraged & Unleveraged & Difference & $p$-value \\
\hline Suitability not checked & 0.543 & 0.614 & 0.502 & 0.112 & 0.056 \\
\hline Age & 55.458 & 55.752 & 55.295 & 0.456 & 0.672 \\
\hline Male & 0.367 & 0.435 & 0.330 & 0.105 & 0.061 \\
\hline Married & 0.886 & 0.913 & 0.871 & 0.042 & 0.253 \\
\hline Income & 17.398 & 18.690 & 16.687 & 2.002 & 0.376 \\
\hline Can calculate compound interest rate & 0.346 & 0.379 & 0.328 & 0.052 & 0.350 \\
\hline Enrolled in high school & 0.566 & 0.590 & 0.553 & 0.037 & 0.516 \\
\hline Stock proportion & 5.457 & 4.855 & 5.791 & -0.936 & 0.508 \\
\hline Bond proportion & 5.599 & 5.397 & 5.710 & -0.313 & 0.833 \\
\hline Deposit proportion & 28.618 & 29.685 & 28.027 & 1.658 & 0.624 \\
\hline
\end{tabular}




\section{Table A4 \\ Suitability Checks and Investments in Structured Products: Subsample Results by Survey Rounds}

This table shows OLS regression results for the suitability check effect on investment allocation using subsamples collected in different periods. We conducted survey from January 14 to June 16, 2009, with the majority of the data collected in March and and May of 2009. The dependent variable is the investment proportion in structured products. Suitability not checked is a dummy variable and equals one if salespeople did not check product suitability before the purchase, and zero otherwise. The $p$-values are in parentheses.

\begin{tabular}{lcc}
\hline Independent & Dependent Variable: Investment Proportion in Structured Products $(\%)$ \\
\cline { 2 - 3 } Variables: & Survey in March 2009 & Survey in May 2009 \\
\hline Suitability not checked & 12.444 & 11.759 \\
& $(0.013)$ & $(0.068)$ \\
Age & 0.097 & -0.687 \\
& $(0.702)$ & $(0.069)$ \\
Male & -12.467 & 9.255 \\
& $(0.019)$ & $(0.170)$ \\
Married & -1.199 & 9.951 \\
& $(0.873)$ & $(0.361)$ \\
Income & -0.355 & 0.029 \\
& $(0.009)$ & $(0.906)$ \\
Annual coupon rate & -4.725 & 0.967 \\
& $(0.099)$ & $(0.738)$ \\
Bank size & 4.708 & -7.026 \\
& $(0.312)$ & $(0.183)$ \\
Interest rate (HIBOR) & -3.998 & 2.813 \\
& $(0.043)$ & $(0.269)$ \\
Constant & 69.659 & 110.146 \\
& $(0.038)$ & $(0.004)$ \\
\hline Observations & 111 & 83 \\
Adjusted $R^{2}$ & 0.130 & 0.046 \\
\hline
\end{tabular}




\section{Table A5 \\ Suitability Checks and Investments in Structured Products: Non-fixed Sample Size}

This table reports OLS regression results compared to Table 2, only with the sample not required to be balanced. In each of the regressions, we select observations that have non-missing data on the variables used in that regression, instead of on all variables that would be used in the 8 regressions. Variable definition is in Table 1 . The $p$-values are in parentheses.

\begin{tabular}{|c|c|c|c|c|c|c|c|c|}
\hline \multirow{2}{*}{$\begin{array}{l}\text { Independent } \\
\text { Variables: }\end{array}$} & \multicolumn{8}{|c|}{ Dependent Variable: Investment Proportion in Structured Products (\%) } \\
\hline & $(1)$ & $(2)$ & $(3)$ & $(4)$ & $(5)$ & $(6)$ & $(7)$ & $(8)$ \\
\hline $\begin{array}{l}\text { Suitability not } \\
\text { checked }\end{array}$ & $\begin{array}{c}9.974 \\
(0.002)\end{array}$ & $\begin{array}{l}10.117 \\
(0.001)\end{array}$ & $\begin{array}{l}10.024 \\
(0.002)\end{array}$ & $\begin{array}{l}10.027 \\
(0.002)\end{array}$ & $\begin{array}{l}10.588 \\
(0.001)\end{array}$ & $\begin{array}{c}8.050 \\
(0.024)\end{array}$ & $\begin{array}{c}8.155 \\
(0.023)\end{array}$ & $\begin{array}{c}8.662 \\
(0.017)\end{array}$ \\
\hline Age & & $\begin{array}{c}-0.146 \\
(0.382)\end{array}$ & $\begin{array}{c}-0.106 \\
(0.534)\end{array}$ & $\begin{array}{c}-0.105 \\
(0.539)\end{array}$ & $\begin{array}{r}-0.130 \\
(0.438)\end{array}$ & $\begin{array}{c}-0.095 \\
(0.629)\end{array}$ & $\begin{array}{c}-0.091 \\
(0.645)\end{array}$ & $\begin{array}{r}-0.097 \\
(0.622)\end{array}$ \\
\hline Male & & & $\begin{array}{c}-4.170 \\
(0.207)\end{array}$ & $\begin{array}{c}-3.900 \\
(0.244)\end{array}$ & $\begin{array}{c}-3.526 \\
(0.283)\end{array}$ & $\begin{array}{c}-4.720 \\
(0.215)\end{array}$ & $\begin{array}{c}-4.652 \\
(0.223)\end{array}$ & $\begin{array}{r}-4.817 \\
(0.207)\end{array}$ \\
\hline Married & & & & $\begin{array}{c}-2.787 \\
(0.586)\end{array}$ & $\begin{array}{c}-0.676 \\
(0.893)\end{array}$ & $\begin{array}{c}0.040 \\
(0.995)\end{array}$ & $\begin{array}{c}0.177 \\
(0.977)\end{array}$ & $\begin{array}{c}0.376 \\
(0.950)\end{array}$ \\
\hline Income & & & & & $\begin{array}{c}-0.293 \\
(0.001)\end{array}$ & $\begin{array}{c}-0.255 \\
(0.019)\end{array}$ & $\begin{array}{c}-0.249 \\
(0.024)\end{array}$ & $\begin{array}{c}-0.262 \\
(0.018)\end{array}$ \\
\hline $\begin{array}{l}\text { Annual coupon } \\
\text { rate }\end{array}$ & & & & & & $\begin{array}{c}-2.318 \\
(0.197)\end{array}$ & $\begin{array}{c}-2.360 \\
(0.190)\end{array}$ & $\begin{array}{r}-1.789 \\
(0.335)\end{array}$ \\
\hline Bank size & & & & & & & $\begin{array}{c}-1.335 \\
(0.678)\end{array}$ & $\begin{array}{c}-1.242 \\
(0.700)\end{array}$ \\
\hline $\begin{array}{l}\text { Interest rate } \\
\text { (HIBOR) }\end{array}$ & & & & & & & & $\begin{array}{r}-1.708 \\
(0.222)\end{array}$ \\
\hline Constant & $\begin{array}{l}54.460 \\
(0.000)\end{array}$ & $\begin{array}{l}62.517 \\
(0.000)\end{array}$ & $\begin{array}{l}61.847 \\
(0.000)\end{array}$ & $\begin{array}{l}64.166 \\
(0.000)\end{array}$ & $\begin{array}{l}68.167 \\
(0.000)\end{array}$ & $\begin{array}{l}79.100 \\
(0.000)\end{array}$ & $\begin{array}{l}86.175 \\
(0.000)\end{array}$ & $\begin{array}{l}87.461 \\
(0.000)\end{array}$ \\
\hline Observations & 298 & 298 & 298 & 298 & 298 & 221 & 221 & 221 \\
\hline Adjusted $R^{2}$ & 0.030 & 0.029 & 0.031 & 0.029 & 0.064 & 0.034 & 0.030 & 0.033 \\
\hline
\end{tabular}




\section{Table A6 \\ Suitability Checks and Investments in Structured Products: Subsample Results by Multi-time Purchases}

This table reports OLS regression results using subsamples based on whether investors have purchased the structured products for multiple times or only once. For investors who purchased structured products for multiple times, we use their first-time purchased products for analysis. This is because investors are required to go through the suitability check only during their first purchases. Moreover, most of the mult-time purchases are due to investors rolling over their first-time investments. Therefore, the effect of suitability check is more prominent for the (immediate) first-time purchases than for the (later) rollover purchases. The $p$-values are in parentheses.

\begin{tabular}{|c|c|c|c|c|c|c|}
\hline \multirow{3}{*}{$\begin{array}{l}\text { Independent } \\
\text { Variables: }\end{array}$} & \multicolumn{6}{|c|}{ Dependent Variable: Investment Proportion in Structured Products (\%) } \\
\hline & \multicolumn{3}{|c|}{ Purchased Only Once } & \multicolumn{3}{|c|}{ Purchased Multiple Times } \\
\hline & $(1)$ & $(2)$ & $(3)$ & $(4)$ & $(5)$ & (6) \\
\hline Suitability not checked & $\begin{array}{c}9.270 \\
(0.039)\end{array}$ & $\begin{array}{c}9.660 \\
(0.032)\end{array}$ & $\begin{array}{l}10.738 \\
(0.019)\end{array}$ & $\begin{array}{c}7.076 \\
(0.218)\end{array}$ & $\begin{array}{c}7.271 \\
(0.205)\end{array}$ & $\begin{array}{c}9.114 \\
(0.145)\end{array}$ \\
\hline Age & & $\begin{array}{c}-0.258 \\
(0.287)\end{array}$ & $\begin{array}{c}-0.219 \\
(0.369)\end{array}$ & & $\begin{array}{c}0.076 \\
(0.829)\end{array}$ & $\begin{array}{c}0.049 \\
(0.894)\end{array}$ \\
\hline Male & & $\begin{array}{c}-4.096 \\
(0.396)\end{array}$ & $\begin{array}{c}-4.510 \\
(0.353)\end{array}$ & & $\begin{array}{c}-6.275 \\
(0.290)\end{array}$ & $\begin{array}{c}-5.969 \\
(0.344)\end{array}$ \\
\hline Married & & $\begin{array}{c}0.652 \\
(0.930)\end{array}$ & $\begin{array}{c}1.297 \\
(0.863)\end{array}$ & & $\begin{array}{c}-1.407 \\
(0.881)\end{array}$ & $\begin{array}{c}-3.688 \\
(0.712)\end{array}$ \\
\hline Income & & $\begin{array}{c}-0.354 \\
(0.064)\end{array}$ & $\begin{array}{c}-0.340 \\
(0.078)\end{array}$ & & $\begin{array}{c}-0.257 \\
(0.039)\end{array}$ & $\begin{array}{r}-0.256 \\
(0.056)\end{array}$ \\
\hline Annual coupon rate & & & $\begin{array}{c}-2.193 \\
(0.356)\end{array}$ & & & $\begin{array}{c}0.664 \\
(0.854)\end{array}$ \\
\hline Bank size & & & $\begin{array}{c}0.864 \\
(0.827)\end{array}$ & & & $\begin{array}{c}-3.891 \\
(0.511)\end{array}$ \\
\hline Interest rate (HIBOR) & & & $\begin{array}{c}-1.988 \\
(0.252)\end{array}$ & & & $\begin{array}{r}-2.246 \\
(0.417)\end{array}$ \\
\hline Constant & $\begin{array}{l}52.754 \\
(0.000)\end{array}$ & $\begin{array}{c}72.338 \\
(0.000)\end{array}$ & $\begin{array}{l}81.376 \\
(0.004)\end{array}$ & $\begin{array}{c}62.763 \\
(0.000)\end{array}$ & $\begin{array}{c}66.660 \\
(0.003)\end{array}$ & $\begin{array}{l}93.159 \\
(0.032)\end{array}$ \\
\hline Observations & 153 & 153 & 153 & 69 & 69 & 69 \\
\hline Adjusted $R^{2}$ & 0.022 & 0.031 & 0.026 & 0.008 & 0.028 & -0.001 \\
\hline
\end{tabular}




\section{Table A7 \\ Suitability Checks and Investments in Structured Products: Subsample Results by Misinterpretation of Products by Salespeople}

This table reports OLS regression results using subsamples based on alleged misrepresentation of structured products by salespeople. The group for Blaming Misrepresentation includes investors alleging that the salespeople did not provide critical product information or provided incorrect information. For example, credit-linked notes include credit events as default of any default of reference entities, but the salespeople may tell the investors that credit event can only be triggered by default of all reference entities. The $p$-values are in parentheses.

\begin{tabular}{|c|c|c|c|c|c|c|}
\hline \multirow{3}{*}{$\begin{array}{l}\text { Independent } \\
\text { Variables: } \\
\end{array}$} & \multicolumn{6}{|c|}{ Dependent Variable: Investment Proportion in Structured Products (\%) } \\
\hline & \multicolumn{2}{|c|}{ Blaming Misinterpretation } & \multicolumn{2}{|c|}{ No Misinterpretation } & \multicolumn{2}{|c|}{ Interaction } \\
\hline & $(1)$ & $(2)$ & $(3)$ & $(4)$ & $(5)$ & $(6)$ \\
\hline Suitability not checked & $\begin{array}{l}7.436 \\
(0.093)\end{array}$ & $\begin{array}{c}8.152 \\
(0.060)\end{array}$ & $\begin{array}{l}13.889 \\
(0.054)\end{array}$ & $\begin{array}{l}15.118 \\
(0.040)\end{array}$ & $\begin{array}{l}13.889 \\
(0.049)\end{array}$ & $\begin{array}{l}16.050 \\
(0.022)\end{array}$ \\
\hline Age & & $\begin{array}{c}-0.141 \\
(0.558)\end{array}$ & & $\begin{array}{r}-0.042 \\
(0.912)\end{array}$ & & $\begin{array}{r}-0.134 \\
(0.509)\end{array}$ \\
\hline Male & & $\begin{array}{r}-2.267 \\
(0.619)\end{array}$ & & $\begin{array}{r}-13.751 \\
(0.097)\end{array}$ & & $\begin{array}{r}-4.838 \\
(0.218)\end{array}$ \\
\hline Married & & $\begin{array}{c}-5.666 \\
(0.432)\end{array}$ & & $\begin{array}{l}26.788 \\
(0.042)\end{array}$ & & $\begin{array}{c}2.636 \\
(0.674)\end{array}$ \\
\hline Income & & $\begin{array}{r}-0.417 \\
(0.002)\end{array}$ & & $\begin{array}{c}-0.426 \\
(0.102)\end{array}$ & & $\begin{array}{r}-0.362 \\
(0.003)\end{array}$ \\
\hline Annual coupon rate & & $\begin{array}{r}-0.994 \\
(0.662)\end{array}$ & & $\begin{array}{l}-1.663 \\
(0.659)\end{array}$ & & $\begin{array}{r}-1.369 \\
(0.480)\end{array}$ \\
\hline Bank size & & $\begin{array}{r}-1.171 \\
(0.761)\end{array}$ & & $\begin{array}{r}-7.771 \\
(0.272)\end{array}$ & & $\begin{array}{r}-3.083 \\
(0.356)\end{array}$ \\
\hline Interest rate (HIBOR) & & $\begin{array}{r}-3.634 \\
(0.038)\end{array}$ & & $\begin{array}{c}1.711 \\
(0.526)\end{array}$ & & $\begin{array}{r}-1.809 \\
(0.216)\end{array}$ \\
\hline Blaming misinterpretation & & & & & $\begin{array}{c}9.861 \\
(0.117)\end{array}$ & $\begin{array}{l}10.966 \\
(0.079)\end{array}$ \\
\hline $\begin{array}{l}\text { Suitability not checked } \\
\times \text { Blaming misinterpretation }\end{array}$ & & & & & $\begin{array}{r}-6.453 \\
(0.437)\end{array}$ & $\begin{array}{r}-7.836 \\
(0.339)\end{array}$ \\
\hline Constant & $\begin{array}{l}57.361 \\
(0.000) \\
\end{array}$ & $\begin{array}{l}98.612 \\
(0.000) \\
\end{array}$ & $\begin{array}{l}47.500 \\
(0.000) \\
\end{array}$ & $\begin{array}{l}81.265 \\
(0.135) \\
\end{array}$ & $\begin{array}{l}47.500 \\
(0.000) \\
\end{array}$ & $\begin{array}{l}87.513 \\
(0.000) \\
\end{array}$ \\
\hline $\begin{array}{l}\text { Observations } \\
\text { Adjusted } R^{2}\end{array}$ & $\begin{array}{c}146 \\
0.013\end{array}$ & $\begin{array}{c}146 \\
0.076\end{array}$ & $\begin{array}{c}60 \\
0.046\end{array}$ & $\begin{array}{c}60 \\
0.072\end{array}$ & $\begin{array}{c}206 \\
0.026\end{array}$ & $\begin{array}{c}206 \\
0.064\end{array}$ \\
\hline
\end{tabular}

